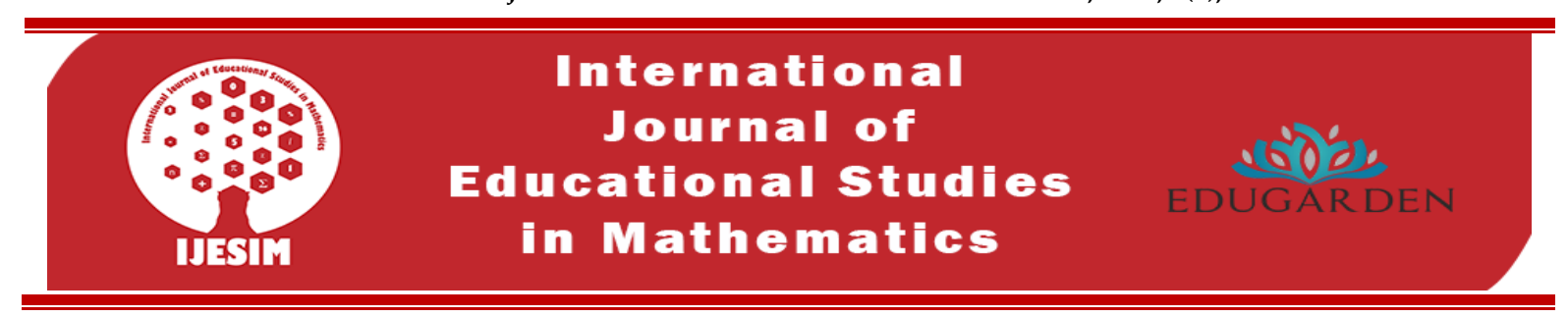

\title{
Classification of Problem-Solving Strategies Based on Mathematical Processing Skills|*
}

\author{
Hasan Temel ${ }^{1}\left(\right.$ D, Murat Altun $^{2}$ (iD
}

${ }_{1}^{1}$ Balıkesir University, Necatibey Education Faculty, Balıkesir, Turkey. ${ }^{2}$ Bursa Uludă̆ University, Education Faculty, Bursa, Turkey.

\begin{tabular}{|c|c|}
\hline ABSTRACT & ARTICLE INFO \\
\hline $\begin{array}{l}\text { It is revealed that problem-solving strategies which play a key role in } \\
\text { terms of problem-solving process are not subjected to a classification. } \\
\text { Through this research study, it is aimed to classify problem solving } \\
\text { strategies that are included mostly in the literature based on } \\
\text { mathematical process skills. The qualitative dimension of the study was } \\
\text { carried out with the data obtained from } 21 \text { students studying in the eighth } \\
\text { grade of a secondary school in Çanakkale City Center. The data collected } \\
\text { by using the "Problem Solving Test (PST)" consisting of eighteen } \\
\text { extraordinary problems for the nine most problem-solving strategies in } \\
\text { the literature were analyzed by the content analysis method by three field } \\
\text { experts and the problem-solving strategies were classified according to } \\
\text { mathematical process skills. As a result of the study, it was found that the } \\
\text { strategies called "Look for a Pattern", "Draw a diagram" and "Use a } \\
\text { Variable" involve both formulation and execution processes; the } \\
\text { strategies of "Make a Systematic List" and "Make a Table" involve only } \\
\text { the execution process; the strategies of "Working Backwards", "Guess } \\
\text { and Check" and "Logical Reasoning" involve both execution and } \\
\text { interpretation, evaluation processes and the strategy of "Simplify the } \\
\text { Problem" involves the processes of formulation, execution and } \\
\text { interpretation, evaluation. }\end{array}$ & $\begin{array}{l}\text { Article History: } \\
\text { Received:29.05.2020 } \\
\text { Received in revised form: } 29.06 .2020 \\
\text { Accepted: } 30.06 .2020 \\
\text { Available online: } 18.09 .2020 \\
\text { Article Type: Standard paper } \\
\text { Keywords: Mathematical literacy, } \\
\text { mathematical processing skills, problem } \\
\text { solving, problem solving strategies. }\end{array}$ \\
\hline
\end{tabular}

\section{Introduction}

When knowledge is combined only with problem solving skills, it brings solutions to vital problems. Therefore, problem-solving is one of the main objectives of teaching programs. Today, international evaluations are used in order to compare and evaluate to what extent education levels appropriate to international standards. Program for International Student Assessment (PISA) is one of these applications and is widely accepted. One of the common goals of these applications is to evaluate mathematics achievements. This is an indicator of the importance of mathematics education at the international level.

In mathematics education, it is necessary to provide individuals with computational skills as well as their mathematical competencies (Umay, 2003). Problem-solving and establishment, mathematical thinking, mathematical modeling and mathematical reasoning are the leading qualifications (Niss and Højgaard, 2019). Because of its importance, problem solving is a need to be addressed in terms of both conceptual and processual terms. In the light of these evaluations, it is seen that two basic concepts including problem solving which is one of the basic objectives of the mathematics curriculum in teaching maths (MoNE, 2018) and mathematics literacy that enables individuals to realize the role of

\footnotetext{
* This study was produced from the doctoral dissertation prepared by the first author under the supervision of the second author.

${ }^{2}$ Corresponding author's address: Balıkesir University, Necatibey Education Faculty, Balıkesir, Turkey.

e-mail: hasan.temel@balikesir.edu.tr

DOI: https://doi.org/10.17278/ijesim.745257
} 
mathematics in real life (Organization for Economic Co-operation and Development [OECD], 2013a) come to the fore.

In studies that deal with problem solving strategies (Altun, 2014; Baykul, 2014; Krulik and Rudnick, 1989; Posamentier and Krulik, 2009; Yazgan and Arslan, 2019), it is seen that strategies are defined generally and sample problems are presented for those strategies. Knowing the problem-solving strategies does not guarantee the solution of the problem, but makes it possible to gain problem solving systematic which increases the probability of reaching the solution (Cai 2003; Altun, 2014). It is thought that the systematic presentation of problem-solving strategies by classifying them will benefit in internalizing problem-solving skills, solving the problems encountered in a meaningful way, determining the strategy for the solution of real-life situations and teaching problem solving strategies.

The main subject of this study is to classify problem solving strategies according to mathematical process skills. Accordingly, the study aimed to classify problem solving strategies that are included in the literature mostly according to mathematical processes (1- Formulating situations and problems mathematically, 2-Using Mathematical concepts, facts, methods, and reasoning 3- Interpreting, applying and evaluating mathematical outputs).

\section{Method}

In this study, one dimension of the thesis study in which problem-solving strategies were classified according to process skills is included. In the classification of problem-solving strategies according to mathematical process skills, a qualitative research method has been adopted in which processes for displaying perceptions and events in a realistic and holistic perspective are followed (Yıldırım, 1999).

The qualitative dimension of the study was carried out with the data obtained from 21 students studying in the eighth grade of a secondary school affiliated to the Ministry of National Education in Çanakkale City Center. In terms of the classification of problem-solving strategies according to process skills "Problem Solving Test (PST)" was used. PST consists of 18 open-ended non-routine problems in total including two problems for each strategies as "Make A Systematic List", "Guess and Check", "Draw a Diagram”, "Look for a Pattern", “Use Variable”, "Simplify the Problem”, “Working Backwards”, "Make a Table" and "Logical Reasoning".

The answer papers for solving the problems in the PST were scanned and transferred to the computer in order to provide the necessary flexibility to the researcher in the process of checking the data analysis, reviewing the codings to be made and analyzing the data (Yıldırım and Şimşek, 2013). Then the data in the computer was sent to 2 field experts for analysis. Along with the researcher, the solutions of the students to the problems were analyzed using content analysis by 3 researchers including 2 field experts (1 Prof. Dr., 1 Ph.D. Student) who have studies on PISA, mathematics literacy and mathematical process skills. The researchers evaluated the solution methods according to whether they include formulation, execution, and interpretation, evaluation processes, and the processes included in the students' solution methods were analyzed by coding as formulation (1), execution (2), interpretation, assessment (3).

\section{Findings}

In the classification of problem-solving strategies according to process skills (formulation, execution and interpretation, evaluation), the solutions of the study group students, who were given problem solving strategies training, were analyzed by 3 experts using the content analysis method.

As a result of the analysis, the strategies of "Make a Systematic List", "Guess and Check", "Draw a Diagram", "Look for a Pattern", "Use a Variable", "Simplify the Problem", "Working Backwards", "Make a Table" and "Logical Reasoning" were classified in terms of formulation, execution and interpretation, evaluation processes.

\section{Discussion, Conclusion and Suggestions}

Mathematical process skills are among the basic skills that should be provided to students (Polat, Bingölbali and Bindak, 2015). However, Bingölbali, Gören and Arslan (2016) stated that teachers could 
not fully explain the mathematical process skills for the gains in the textbooks and Özgen (2019) stated that teachers and prospective teachers had difficulties in posing problems in terms of mathematical process skills. Ülger, Bozkurt and Altun (2020), on the other hand, indicated that problems were encountered in terms of mathematical process skills in mathematical literacy problems and emphasized that practices related to processes should be increased.

When the studies conducted are taken into consideration, it is seen that teachers and students have problems in mathematical process skills. This situation is thought to be due to the lack of adequate studies in the literature on how to gain mathematical processes, how to plan trainings for mathematical processes and what kind of practices and activities will contribute to process skills (Erdoğan and Özdemir-Erdoğan, 2013). In addition, it has been revealed that the majority of the studies on mathematical process skills are limited to descriptive descriptions, and the studies that produce solutions for the existing problem are not sufficient (Ülger, Bozkurt and Altun, 2020). Contribution to the development of mathematical process skills can be made in line with the trainings to be designed considering the classification made. The classification is thought to shed light on the answer to the questions of how to acquire mathematical process skills, what kind of practices and activities will have a positive effect on process skills. Accordingly, the development of relevant process skills can be examined by using problems for problem solving strategies classified according to process skills.

Within the framework of the classification introduced, new research studies can be carried out to determine whether the related process skills of the students are developed by teaching the related problem-solving strategies. Based on the problems of formulation, execution and interpretation, evaluation process skills, studies on which problem-solving strategies these problems involve can also be put forward. Through the classification, studies can be carried out to reveal whether there are differences between the teaching of strategies that contain a process skill or multiple process skills, and the effect of these situations on students' mathematics literacy success levels. 


\section{Problem Çözme Stratejilerinin Matematiksel Süreç Becerilerine Göre Sinıflandırılması*}

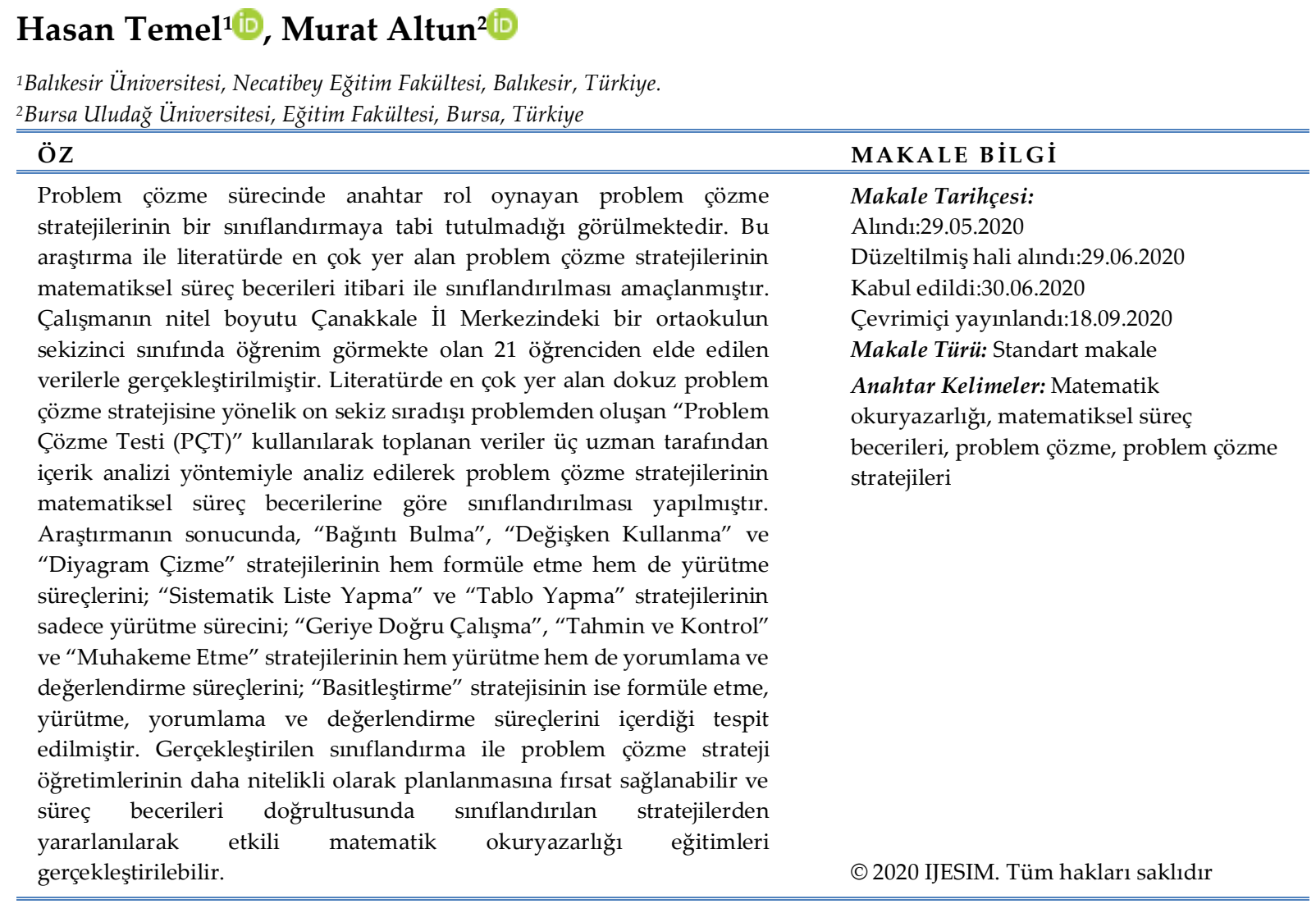

\section{Giriş}

Bilgi, ancak problem çözme becerileri ile birleştirildiğinde yaşamsal problemlere çözüm getirmektedir. $\mathrm{Bu}$ yüzden problem çözme öğretim programlarının temel hedefleri arasında yer almaktadır. Günümüzde eğitim düzeylerinin uluslararası standartlara göre ne ölçüde uygun olduğunun karşılaştırılması ve değerlendirilmesi amacıyla uluslararası değerlendirmelerden yararlanılmaktadır. Uluslararası düzeyde gerçekleştirilen Uluslararası Öğrenci Değerlendirme Programı (Programme for International Student Assessment [PISA]) bu uygulamalardan biridir ve yaygın kabul görmektedir. Bu uygulamaların ortak hedeflerinden biri matematik başarılarının değerlendirilmesidir. Bu durum uluslararası düzeyde matematik eğitimin ne derece önemli olduğunun bir göstergesidir.

Matematik eğitiminde bireylere sadece hesaplama becerilerini kazandırmanın yanı sıra matematiksel yeterliliklerinin de kazandırılması gerekmektedir (Umay, 2003). Bu yeterliliklerin başında problem çözme ve kurma, matematiksel düşünme, matematiksel modelleme ve matematiksel akıl yürütme gelmektedir (Niss ve Højgaard, 2019). Problem çözme bu öneminden ötürü gerek kavramsal açıdan gerekse süreç bakımından her yönüyle ele alınması gereken bir ihtiyaçtır. Bu değerlendirmeler ışı̆̆ında matematik eğitiminde, matematik öğretim programının temel amaçları arasında yer alan (MEB, 2018) problem çözme ve bireylerin matematiğin gerçek yaşamdaki rolünü fark etmelerini sağlayan (Organisation for Economic Co-operation and Development [OECD], 2013a) matematik okuryazarlğgl olmak üzere iki temel kavramın ön plana çıktığı görülmektedir.

Temel kavramlardan biri olan problem çözme becerileri, gerçek yaşamda karşılaşılan problemlerin çözümünde, bilgi ve becerilerin geliştirilmesinde ve bu bilgi birikiminin sonraki problem durumlarına

* Bu çalışma, birinci yazarın ikinci yazar danışmanlığında hazırladığı doktora tezinden üretilmiştir. 
aktarılmasında önemli rol oynamaktadır. Rutin olmayan problemlerin kullanımı öğrencilerin problem çözme becerilerinin gelişmesine katkı sağlamaktadır (Mabilangan, Limjap ve Belecina, 2011; Stanic ve Kilpatrick, 1988). Rutin olmayan problemlerin apaçı bir çözüm yönteminin bulunmaması problemlerin çözümünde yaratıcı düşünme (Elia, Van den Heuvel-Panhuizen, ve Kovolou, 2009), muhakeme etme ve üst düzey düşünme becerilerini gerektirmektedir (Kolovou, Van den HeuvelPanhuizen ve Bakker, 2009). Dolayısıyla rutin olmayan problemlerle ilgili çalışmalar, öğrencilerin yaratıcı düşünme, ilişki-örüntü arama ve ispat becerilerini geliştirir (Altun, 2014). Matematik derslerinde öğrencilere rutin olmayan problemler yöneltilerek öğrencilerin problem çözme becerilerini geliştirmeleri için fırsatlar sunulmalıdır (MEB, 2013). Yapılan çalışmalar göstermektedir ki; öğrencilere problem çözme stratejilerinin öğretimi rutin olmayan problem çözme becerilerinin gelişimine katkı sağlamaktadır (Altun ve Arslan 2006; Altun ve Memnun, 2008; Artut ve Tarım, 2006; Çelebioğlu ve Yazgan 2009; Dönmez, 2002; Elia ve diğerleri, 2009; Yazgan ve Bintaş, 2005; Yazgan, 2007).

Problem çözme ve rutin olmayan problemlerin çözümündeki başarı problem çözme stratejilerinin kullanımıyla paralellik göstermektedir (Cai, 2003). Problem çözme stratejilerinin üst bilişle ilgili olması (Ramnarain, 2014), öğrencilere bilişsel süreçleri açıklaması ve yansıtmasında yarar sağlaması (Ramnarain, 2014), öğrencilerin farklı fikir ve yaklaşımları görmelerine imkan tanıması (Woodward, Beckmann, Driscoll, Franke, Herzig, Jitendra, Koedinger... ve Ogbuehi, 2012) ve problemlerin çözümünde anahtar rolünü üstlenmesi (Schoenfeld, 1999) problem çözme stratejilerinin matematik eğitimindeki önemini ortaya koymaktadır. Problem çözme stratejilerinin konu edildiği çalısmalarda (Altun, 2014; Baykul, 2014; Krulik ve Rudnick, 1989; Posamentier ve Krulik, 2009; Yazgan ve Arslan, 2019) stratejilerin genel olarak tanımlaması yapılarak stratejilere yönelik örnek problemler sunulmaktadır. Problem çözme stratejilerinin bilinmesi problemin çözümünü garanti etmez fakat, çözüme ulaşma olasılığını arttıran problem çözme sistematiğini kazandırır (Cai 2003; Altun, 2014) Problem çözme stratejilerinin sinıflandırılarak sistematik olarak sunulmasının, problem çözme becerilerinin içselleştirilmesinde, karşılaşılan problemlerin anlamlı olarak çözüme kavuşturulmasında, gerçek yaşam durumundaki problemlerin çözümü için strateji belirlenmesinde ve problem çözme stratejilerinin öğretiminde yarar sağlayacağı düşünülmektedir.

Son zamanlarda matematik eğitiminde problem çözme gibi öne çıkan bir diğer kavram matematik okuryazarlığıdır. Matematik okuryazarlığı genel olarak bağlam içerisinde sunulmuş problemle ölçülmektedir (Stacey ve Turner, 2015). Matematik okuryazarlığına sahip bir birey, günlük hayat bağlamında karşılaştığı bir problemi formüle ederek matematiksel ortama aktarabilir, matematiksel olarak ifade edilen problemi sahip olduğu bilgi ve becerileri kullanarak çözebilir ve matematiksel dünyada elde etiği sonuçları gerçek yaşam durumuna göre yorumlayabilir. OECD (2009; 2013b) matematik okuryazarlığını içerik, matematiksel süreçler ve durumlar olmak üzere üç boyutta ele almaktadır. PISA uygulamalarında matematiksel süreçler öncelik verilen konu alanlarından biridir ve matematik okuryazarlığı tanımı bu süreçlere atıfta bulunmaktadır (OECD, 2013b). Genel matematiksel yeterlilikler olarak ifade edilen matematiksel süreçler (OECD,2009), "Durumları matematiksel olarak formülleştirme (formüle etme)", "Matematiksel kavram, olgu, süreç ve akıl yürütmeleri işe koşma (Yürütme)" ve "Matematiksel çıktıları yorumlama, uygulama ve değerlendirme (YorumlamaDeğerlendirme)" olmak üzere üç matematiksel sürecin tanımı yapılmaktadır (OECD, 2013b).

Matematik öğrenmelerde matematiksel süreçler önemli yetkinlikler arasında yer almaktadır (Mohd ve Mahmood, 2011). Çünkü beceriler, verilen kavramlara göre öğrencilerin bir problemi doğru ve mantıksal olarak çözme yeteneğini arttırmaktadır (Kaosa-ard, Erawan, Damrongpanit ve Suksawang, 2015). Matematiğin doğasının tanınmasında, matematiksel bilgilerin kazanılmasında ve bu bilgilerin günlük hayatta karşılaşılan problemlerin çözümünde kullanılmasında matematiksel süreç becerilerinden yararlanılmaktadır (Erdoğan ve Özdemir-Erdoğan, 2013). Matematiksel süreçler matematiksel kavramların kazandırılması, kavramlar arasındaki ilişkilerin fark edilmesi, matematiğin etkili olarak kullanılması ve anlamlı öğrenmelerin gerçekleşmesinde etkin rol üslenmektedir (MEB, 2013). Dolayısıyla matematiksel süreç becerileri matematik öğretiminde öğrencilere kazandırılması gereken temel hedefler arasında yer almaktadır (Polat, Bingölbali ve Bindak, 2015). 
Matematiksel süreç becerileri yaratıcı ve eleştirel olarak problemlerin tanımlanmasına, kurulmasına ve çözülmesine olanak sağlamaktadır (Kaosa-ard vd., 2015). Öğrenciler bu becerilerden yoksunsa karşılaşılan problem durumlarını matematiksel dile dönüştürmede, matematiksel dünyada kavramlar arasındaki ilişkileri fark etmede, problemlere yönelik çözüm yöntemi geliştirmede ve elde edilen çözümü yorumlama ve değerlendirmede zorlanmaktadır. Bu doğrultuda matematiksel süreçlerin belirli bir durum veya matematikle ilgili problemleri cevaplamak ve çözmek için matematiksel kavramların işe koşulmasını sağlayan beceriler olduğu söylenebilir (Grouws, 1999). Bu görüşler 1şığında, okullarda kullanılan matematik öğretimi etkinlikleri öğrencilerin matematiksel süreç becerilerini geliştirmeye odaklanmalıdır (Reys, Lindquist, Lambdin ve Smith, 2007). Matematiksel süreçlerin öğretim uygulamasına sistematik olarak dahil edilmesiyle, bu süreçler öğrencilerin matematiksel yeterliliklerinin geliştirilmesinde önemli bir rol oynayacaktır (Alsina, Maurandi, Ferre ve Coronata, 2020). Fakat, Literatürde matematiksel süreçlerin nasıl kazandırılacağı, farklı süreçler arasındaki ilişkilerin ve aktarımların nasıl olduğu, matematiksel süreçlere yönelik eğitim ortamlarının nasıl düzenlenmesi gerektiği ve hangi etkinliklerin ve uygulamaların hangi süreçler üzerinde etkili olduğuna yönelik soruları cevaplayacak yeterince çalışma bulunmamaktadır (Erdoğan ve ÖzdemirErdoğan, 2013).

Literatürde problem çözme stratejilerinin sınıflandırıldığı bir çalışma ile karşılaşılmamakla birlikte problem çözme ve matematik okuryazarlığın birlikte incelendiği çok az sayıda çalışma yer almaktadır. Bu çalışmalardan biri Akyüz ve Pala (2010) tarafından gerçekleştirilmiştir. Çalışmada Türkiye, Finlandiya ve Yunanistan'a ait PISA 2003 verilerini kullanarak, öğrencilerin matematik okuryazarlıklarına ve problem çözme becerilerine etki eden öğrenci, aile ve sınıf ile ilgili faktörleri araştırmıştır. Elde edilen bulgular doğrultusunda matematik okuryazarlığı ve problem çözme arasında, matematiğe karşı tutumları ile matematik okuryazarlıkları arasında anlamlı bir ilişki olduğu, üç ülkenin verilerine göre öğrenci ailelerinin eğitim düzeylerinin ve mesleklerinin, öğrencilerin matematik okuryazarlıklarını ve problem çözme becerilerini pozitif yönde etkilediği sonucuna ulaşılmıştır. Soytürk (2011) ise çalışmasında sınıf öğretmen adaylarının matematiksel problem çözme inançları ile matematik okuryazarlığı öz yeterliklerini incelemiştir. Öğretmen adaylarının matematik okuryazarlık öz yeterliği ile matematiksel problem çözme inançları arasında pozitif yönde anlamlı ilişkinin olduğu sonucuna ulaşılmıştır. Çilingir ve Artut (2016) ise ilkokul düzeyinde Gerçekçi Matematik Eğitiminin (GME), öğrencilerin matematik başarılarına, görsel matematik okuryazarlık özyeterlik algılarına ve matematik problemlerini çözmeye yönelik tutumlarına etkisini incelemiştir. Çalışma sonucunda GME'nin görsel matematik okuryazarlığı özyeterlik algıları ve problem çözme becerilerine ilişkin tutumlarda etkili olduğuna ulaşılmıştır. Özdemir, Duran ve Kaplan (2016) ise ortaokul düzeyinde görsel matematik okuryazarlığı özyeterlik algıları ile problem çözme beceri algıları arasındaki ilişkiye odaklanmıştır. Elde edilen sonuçlara göre görsel matematik okuryazarlığı özyeterlik algısı ile problem çözme beceri algısı arasında düşük düzeyde, pozitif yönde anlamlı bir ilişki olduğu ortaya konulmuştur.

Öğrenciler problem çözme etkinliklerinde gerçek yaşam durumlarıyla matematik arasında bağlantı kurmayı öğrenirler (Niss, Blum ve Galbraith, 2007). Bu tür etkinliklerle, öğrencilerin matematiksel süreçlere katılımı sağlanabilir ve bunun sonucunda öğrencilerin süreç becerileri geliştirilebilir (Reys, Lindquist, Lambdin ve Smith, 2007). Başka bir ifadeyle problem çözme stratejileri süreç becerilerinin gelişimine katkı sağlayabilir. Bu duruma farklı bir açıdan bakıldığında süreç becerileri problemlerin doğru ve mantıksal olarak çözülmesini sağladığı (Erdoğan ve Özdemir-Erdoğan, 2018; Kaosa-ard vd., 2015) gibi uygun stratejisinin belirlenmesi ve stratejinin uygulanması da problemlerin çözümüne katkı yapmaktadır. Dolayısıyla matematiksel süreç becerileri ile problem çözme stratejileri arasında bir ilişki bulunmaktadır. Problemlerin çözümüne yönelik stratejilerinin seçiminde ve uygulanmasında matematiksel süreç becerileri işe koşulması bu ilişkinin bir göstergesidir. Problem çözme stratejilerinin matematiksel süreç becerilerinin gelişimine olumlu yönde etkisi olduğu gibi matematiksel süreç becerilerinin de problem çözme stratejilerinin kullanımı ve uygulamasında etkisi bulunmaktadır. Bu görüşler doğrultusunda, problem çözme stratejilerinin matematiksel süreç becerilerine göre sınıflandırılmasının Erdoğan ve Özdemir-Erdoğan'ın (2013) çalı̧̧malarında belirttikleri literatürde 
matematiksel süreçlerin nasıl kazanılacağı, süreç becerilerine yönelik hangi etkinliklerin ve uygulamaların süreçler üzerinde etkili olduğu sorularının cevaplarının yeterince olmamasına bir nebze de olsa 1şık tutacağı düşünülmektedir.

Matematik okuryazarlığı süreçleri ile ilgili bilgi ve beceri kazanıldığında, bu birikim karşılaşılabilecek başka problemlerde de kullanabilir. Elde edilen deneyimlerin başka problem durumlarına transferinde problem çözme stratejilerinin de etkisi bulunmaktadır. Bu doğrultuda matematik eğitiminin temel amaçlarından biri öğrencilerin problem çözme becerilerinin geliştirilmesi olarak görülmüş (MEB, 2013; MEB, 2018) ve öğrencilerin yeterli düzeyde bilgi ve becerilerle donatılarak matematiksel okuryazar olması gerektiği vurgulanmıştır (Akkaya ve Memnun, 2012). Matematik okuryazarlığı literatüründe problemler çözümlerinin gerektirdiği süreç becerilerine göre formüle etme, yürütme, yorumlama ve değerlendirme olmak üzere üç kategoride sinıflandırılmaktadır (OECD, 2013a; OECD, 2013b). Formüle etme, gerçek yaşamın matematiksel olarak formüle edilmesini, yürütme matematiksel olarak formüle edilen problemlerin çözümünde matematiksel kavram, olgu ve muhakemelerin işe koşulmasını, yorumlama değerlendirme ise matematiksel sonucun gerçek dünyada yeniden yorumlanması ve matematiksel çözümün gerçek dünyada değerlendirilmesini gerektirmektedir (OECD, 2013b). Bu süreçler öğrencilerin problemleri doğru ve mantıklı çözmelerine olanak sağlar. Bu bakımdan problem çözme stratejilerinin formüle etme, yürütme ve yorumlama değerlendirme süreç becerilerine göre sınıflandırılması, matematik eğitiminde süreç becerilerinin nasıl kazandırılması gerektiği, süreç becerilerinde etkili olan stratejilerin ortaya konulması ve daha planlı ve sistematik olarak problem çözme stratejilerinin öğretiminin tasarlanmasına olanak sağlamasıyla problem çözme literatürüne farklı bir boyut kazandırabilir. Süreçlerin her birinde etkin olan stratejilerin belirlenmesinin strateji öğretiminin daha nitelikli olarak planlanabilmesine olanak sağlayacağı düşünülmektedir.

\section{1. Çalışmanın Amacı ve Önemi}

$\mathrm{Bu}$ çalışmanın ana konusu problem çözme stratejilerini matematiksel süreç becerilerine göre bir sınıflamaya tabi tutmaktır. Bu doğrultuda çalışmada literatürde en çok yer alan problem çözme stratejilerinin matematiksel süreçlere (1- Durumları, problemleri matematiksel olarak formüle etme, 2Matematiksel kavramları, gerçekleri, yöntemleri kullanma ve akıl yürütme 3- Matematiksel çıktıları yorumlama, uygulama ve değerlendirme) göre sınıflandırılması amaçlanmıştır.

Problem çözmenin sistematiğini kazanan bir öğrenci nerde, neyi ve niçin yaptığının farkında olur (Altun, 2014). Problem çözme stratejilerinin matematiksel süreç becerilerine göre sınıflandırılmasının öğrencilerin öğrendikleri bilgiler ile gerçek yaşam durumları arasında bağlantı kurmalarını kolaylaştıracağı, bu sınıflandırma ile problem çözme stratejilerinin içerdiği süreçler ortaya konularak daha nitelikli öğrenmeye katkı sunabilir. Problem çözme stratejilerin süreç becerilerine göre sınıflandırılmasının, bu stratejilere ilişkin matematiksel bilgilerin etkili bir şekilde algılanmasını, içselleştirilmesini sağlayacağı söylenebilir. Ortaokul matematik öğretim programı incelendiğinde, programda problem çözme stratejilerinin eğitimine ve öğretimine ilişkin ayrıntılı bilgilerin yer almadığı, sınıf düzeylerine göre problem çözme stratejilerinin sinıflandırılmadığı ve bir problemin çözümüne ilişkin problem çözme stratejilerinin detaylı olarak yer almadığı görülmektedir. Problem çözme stratejilerinin matematiksel süreç becerilerine göre sinıflandırılması stratejilerin içerdiği süreçlerin belirlenmesine imkân sağlayarak gerçekleştirilecek olan problem çözme strateji eğitimlerinin sistemli olarak öğretilmesine katkı sağlayacağı düşünülmektedir. Bu eğitimlerin yapılan sınıflandırma doğrultusunda bir süreç becerisini içeren stratejiler, daha sonra birden fazla süreç becerisini içeren stratejiler şeklinde gerçekleştirilmesinin etkili ve kalıcı öğrenme sağlayacağ düşünülmektedir. Ayrıca böyle bir sınıflandırma ile öğrencilerin bilişsel gelişim düzeyleri dikkate alınarak bu doğrultuda problem çözme stratejilerinin öğretiminin de gerçekleştirilebileceği ve bu durumdan hareketle problem çözme stratejileri eğitimine yeni bir bakış açısı getireceği söylenebilir.

Genel olarak bu çalışmadan iki temel yarar beklenebilir. Bunlardan birincisi problem çözme süreçlerinin her birinde etkin olan strateji(-lerin) belirlenmesi ile problem çözme strateji öğretiminin daha nitelikli olarak planlanmasına fırsat sağlayarak problem çözme eğitimine yararı olabilir. İkincisi ise elde edilecek 
sonuçların matematik okuryazarlığı eğitimine katkısı olabilir. Süreç becerilerinde kullanılan stratejilerin işe koşulması ile daha nitelikli matematik okuryazarlığı eğitimleri hazırlanabilir.

\subsection{Araştırma Problemi}

Matematiksel süreçlerin her birinde hangi problem çözme stratejileri yer almaktadır?

\subsection{Araştırmanın Alt Problemleri}

Problem çözme stratejilerinden hangisi(-leri) formüle etme sürecinde yer almaktadır?

Problem çözme stratejilerinden hangisi(-leri) yürütme sürecinde yer almaktadır?

Problem çözme stratejilerinden hangisi(-leri) yorumlama, değerlendirme sürecinde yer almaktadır?

\section{Yöntem}

Bu çalışmada problem çözme stratejilerinin süreç becerilerine göre sınıflandırıldığı tez çalışmasının bir boyutuna yer verilmiştir. Problem çözme stratejilerinin matematiksel süreç becerilerine göre sınıflandırılma aşamasında, algı ve olayların gerçekçi ve bütüncül bir bakış doğrultusunda ortaya konulmasına yönelik süreçlerin izlendiği nitel araştırma yöntemi benimsenmiştir (Yıldırım, 1999). Nitel araştırma, kuram oluşturmayı merkeze alan bir düşünceyle sosyal olguları ilişkili oldukları çevre içerisinde araştırmayı ve anlamayı önde tutan bir yaklaşım olarak ifade edilmektedir (Yıldırım ve Şimşek, 2013). Yapılan tanımlamadan yola çıkarak nitel araştırmada, toplanan verilerden hareketle daha önce ortaya konulmamış ilişkileri açıklayan bir model ortaya konulabileceğini de söyleyebiliriz. Bu doğrultuda nitel araştırma yöntemi kullanılarak araştırmanın ilk üç alt problemiyle ilişkili olan problem çözme stratejilerinin matematiksel süreç becerileriyle ilişkilerine göre sinıflandırılması gerçekleştirilmiştir.

\section{1. Çalışma Grubu}

Çalışmanın nitel boyutu Çanakkale İl Merkezindeki Millî Eğitim Bakanlığına bağlı bir ortaokulun sekizinci sınıfında öğrenim görmekte olan 21 öğrenciden elde edilen verilerle gerçekleştirilmiştir. Çalışma grubunun seçildiği okul 2015-2016 Eğitim Öğretim yılının Güz döneminde uygulanan Temel Eğitimden Ortaöğretime Geçiş (TEOG) Sınavına göre genel puan ve matematik puanı olarak Türkiye ortalamasının ve Çanakkale ortalamasının üzerinde bir okuldur. Problem çözmenin üst düzey beceriler gerektirmesi (Iş̧1k ve Kar, 2011) ve öğrencilerin bilişsel gelişim düzeyinin problem çözmede önemli olması (Kaytancı, 1998; Azak, 2015) dikkate alınarak araştırmanın gerçekleştirilmesinde iyi düzeyde bir okul tercih edilmiştir. Ayrıca belirlenen okulun araştırmacıya her türlü imkânı tanıması ve gereken desteği vermesi, çalışmanın bu okulda yürütülmesinin bir diğer sebebidir.

Araştırmanın sekizinci sınıf düzeyindeki öğrencilerden seçilmiş olmasının sebebi, rutin olmayan problemlerin daha üst düzey beceri gerektirmesi, problem çözme becerilerinin üst sınıflara doğru gelişim göstermesi (Işık ve Kar, 2011) ve düşük sınıf düzeylerinde rutin olmayan problem çözme başarılarının oldukça düşük olmasıdır (Olkun, Şahin, Akkurt, Dikkartın ve Gülbağcı, 2009). Ortaokul düzeyinde sekizinci sınıf öğrencilerinin diğer sınıf düzeyindeki öğrencilere göre problem çözmede daha başarılı olmaları (Altun ve Arslan, 2006) ve sekizinci sınıf düzeyindeki öğrencilerin bilişsel gelişim düzeylerinin diğer sınıf düzeyindeki öğrencilerden yüksek olması araştırmanın sekizinci sınıf düzeyinde yürütülmesinin bir başka nedenidir.

Problem çözme stratejilerinin matematik süreç becerilerine göre sınıflandırılması amacı doğrultusunda uygun sonuçların elde edilmesi uygun grupla çalışmayı gerektirmektedir. Sekizinci sınıf öğrencilerinin bilişsel olarak diğer sınıf seviyelerine göre daha iyi düzeyde olması, problem çözmede ve strateji kullanmada daha başarıları olmaları bakımından çalışma sekizinci sınıf düzeyindeki öğrencilerle gerçekleştirilmiştir. Öğrencilerin matematik okuryazarlık düzeylerini ortaya koyan PISA uygulamalarının da 15 yaş grubu (sekizinci sınıf düzeyi) öğrencilerle gerçekleştiriliyor olması çalışmanın sekizinci sınıf düzeyindeki öğrencilerle gerçekleştirilmesinin temel nedenleri arasındadır. 
Çalışmanın gerçekleştirildiği grubun özellikleri incelendiğinde 21 öğrencinin 11'i kız (\%52,4) ve 10'u $(\% 47,6)$ erkektir. Öğrenciler 2015-2016 Eğitim Öğretim yılının Güz döneminde uygulanan TEOG sınav1 matematik başarı puanları incelendiğinde iyi (85-100 puan) düzeyde 7, orta (55-84 puan) düzeyde 7 ve düşük (0-54 puan) düzeyde 7 öğrenci bulunmaktadır. Bu durum bilgi açısından zengin durumların seçilerek derinlemesine inceleme yapılmasına ve evrende çeşitlilik gösteren öğrencilerin temsiline olanak sağlamaktadır (Büyüköztürk, Çakmak Kılıç, Akgün, Karadeniz ve Demirel, 2014). Katılımcıların özeline ve gizliliğine saygı gösterilmesi (Creswell, 2013) ve kimliklerinin korunması adına öğrenciler D1, D2, D3...şeklinde kodlanmıştır.

\subsection{Veri Toplama Arac1}

Problem çözme stratejilerinin süreç becerilerine göre sınıflandırılmasında "Problem Çözme Testi (PÇT)"nden yararlanılmıştır. PÇT'de yer alacak problemlerin belirlenmesinde öncelikle genel olarak ve ilkokul-ortaokul düzeyinde problem çözme stratejilerinin yer aldığı 45 çalışma incelenmiştir. Yapılan inceleme sonucunda literatürde en çok yer alan problem çözme stratejilerinin "Sistematik Liste Yapma", "Tahmin ve Kontrol", "Diyagram Çizme", "Bağıntı Bulma", "Değişken Kullanma", "Basitleştirme", "Geriye Doğru Çalışma", "Tablo Yapma" ve "Muhakeme Etme" stratejilerinin olduğu belirlenmiştir. PÇT'deki problemlerin; literatürde yer alan, belirlenen stratejiyi temsil edebilecek ve ilgili strateji ile çözülebilecek problemlerden seçilmesi kararlaştırılmıştır. Bu doğrultuda stratejiler için problem havuzları oluşturularak literatürde ilgili strateji altında verilen problemler ilgili olduğu stratejinin problem havuzuna dahil edilmiştir. Her bir strateji için ilgili olduğu stratejiyi temsil edebilecek ve belirtilen strateji ile çözülebilen iki problem seçilerek toplamda 18 açık uçlu rutin olmayan problemden oluşan PÇT oluşturulmuştur.

Bir testten elde edilen puanların ölçülmek istenilenin iyi bir temsilcisi olması, testteki maddelerin ölçülmek istenilen davranışı yeteri düzeyde temsil edebilecek bir yapıda olmasını gerektirir (Büyüköztürk, 2014). Testteki maddelerin yanlış anlaşılması veya doğru algılanamaması durumunda ölçülmek istenilen davranış tam olarak yansıtılamayabilir. Bu doğrultuda ölçülmek istenen durumun başka durumlarla karıştırılmaması adına PÇT'deki problemlerin anlaşılabilirliğinin, yazım ve ifade açısından uygunluğunu belirlemek üzere 4 dil uzmanın (2 Dr. Öğr. Üyesi, 2 Doktora öğrencisi) görüşlerine başvurulmuştur. Uzman görüşleri doğrultusunda bazı problemlerin anlaşılabilirliğini sağlamak amacıyla yazım ve ifade açısından düzeltmeler yapılmıştır. PÇT'deki 18 problem için belirlenen problem çözme stratejisiyle çözülebilmesi ve sekizinci sinıf (15 yaş grubu) öğrencilerinin düzeyine uygunluğu açısından değerlendirilmek üzere uzman değerlendirme formları oluşturularak problem çözme testindeki maddelerin ölçülmek istenilen davranışı yeterince yansıtıp yansıtmadığını ortaya koymak amacıyla uzman görüşlerine başvurulmuştur. Uzman görüşlerinde geliştirilmek istenilen "PÇT'nin ölçmenin amacına uygun olup olmadığı", "Test, ölçülmek istenilen davranışı yeterince yansıtıyor mu?", "Maddeler ölçmeye çalıştığımız şeyi yetirince temsil ediyor mu?" sorularına cevap aranmıştır (Büyüköztürk ve diğerleri, 2014; Johnson ve Christensen, 2014; Karasar, 2008). Ölçeğin kapsam geçerliğini incelemede kullanılan yöntemlerden biri de uzman görüşüne başvurmaktır (Büyüköztürk ve diğerleri, 2014; Karasar, 2008). Uzman görüşleri doğrultusunda PÇT'deki problemlerin belirtilen stratejilerle ilgili olduğu ve sekizinci sinıf düzeyine uygun olduğu ortaya konulmuştur.

Geçerliğe ilişkin uzman görüşü alıp pilot uygulama gerçekleştirildikten sonra problem çözme testinin güvenirliği incelenmiştir. Karasar (2008, s. 148) güvenirliği, "aynı şeyin bağımsız ölçümleri arasındaki kararlılıktır; ölçülmek istenilen bir şeyin, sürekli olarak aynı sembolleri almasıdır; aynı süreçleri izlemesi ve aynı ölçütlerin kullanılması ile aynı sonuçların alınmasıdır; ölçmenin tesadüfi yanılgılardan arınık olmasıdır" şeklinde tanımlamaktadır. Bu doğrultuda ilgili testin iç tutarlılık katsayısı (KR-20 $\alpha=0,86$ ) ve test tekrar test güvenirlik ölçütü (Pearson Korelasyon Katsayısı= 0,91) hesaplanmıştır.

Çalışma grubuyla gerçekleştirilen problem çözme strateji eğitiminden sonra "Problem Çözme Testi" öğrencilere uygulanarak veriler toplanmıştır. PÇT'nin içerdiği 18 açık uçlu rutin olmayan problemlere 
ilişkin öğrenci cevapları ayrıntılı olarak incelenerek, problemlerin çözümlerinin hangi süreç becerilerini içerisinde barındırdığı analiz edilmiştir.

\subsection{Uygulama Süreci}

Stratejilerin matematiksel süreç becerilerine göre sınıflandırılma aşamasından önce öğrencilerin stratejileri tanımaları ve kavramalarının da sağlanması adına 5 haftalık problem çözme stratejileri eğitimi gerçekleştirilmiştir. Eğitimler literatürde en çok yer alan dokuz problem çözme stratejisine yönelik hazırlanan ders planları çerçevesinde yürütülmüştür. Uygulama öncesinde, gerçekleştirilecek strateji eğitimlerine yönelik pilot çalışma gerçekleştirilerek ders planların son hali verilmiştir. Her bir stratejiye yönelik dört uygulama problemini içeren ders planlarıyla 5 haftalık (10 ders saati) zaman diliminde uygulama gerçekleştirilmiştir.

\subsection{Verilerin analizi}

Araştırmanın nitel verileri, çalışma grubuyla gerçekleştirilen problem çözme strateji eğitiminden sonra uygulanan PÇT'den elde edilmiştir. PÇT'deki problemlerin çözümüne yönelik cevap kağıtları, veri analizlerini kontrol etme, yapılacak olan kodlamaları gözden geçirme ve verilerin analizi sürecinde araştırmacıya gerekli esnekliği sağlaması adına taratılarak bilgisayar ortamına aktarılmıştır (Yıldırım ve Şimşek, 2013). Daha sonra bilgisayar ortamındaki veriler analiz edilmek üzere 2 alan uzmanına gönderilmiştir. Araştırmacıyla beraber PISA, matematik okuryazarlığı ve matematiksel süreç becerilerine yönelik çalışmaları bulunan 2 alan uzmanı (1 Prof. Dr., 1 Doktora Öğrencisi) olmak üzere 3 araştırmacı tarafından öğrencilerin problemlere yönelik çözümleri içerik analizi yöntemiyle analiz edilmiştir. Araştırmacılar çözüm yöntemlerini formüle etme, yürütme, yorumlama değerlendirme süreçlerini içerip içermemesine göre değerlendirerek öğrencilerin çözüm yöntemleri içerisinde yer alan süreçler formüle etme (1), yürütme (2), yorumlama değerlendirme (3) şeklinde kodlanarak analiz edilmiştir.

Nitel veri analizinin güvenirliği için güvenirlik formülü (Güvenirlik: Görüş Birliği / Görüş Birliği +Görüş Ayrılığı X 100) hesaplanmıştır (Miles ve Huberman, 1994). Bu formüle göre iki veya daha fazla uzman tarafından belirlenen kodlar doğrultusunda veriler kodlanarak analiz edilir. Yapılan kodlamalar sonucunda araştırmacılar arasında görüş birliğine varılan ve görüş ayrılığına düşülen kodlar belirlenerek uzmanların görüşleri arasındaki uyum oranı ortaya konulmaktadır. Birden fazla uzmanın ortaya çıkan kodlama benzerliği ve farklılığı karşılaştırılarak bir kodlama yüzdesi elde edilir. Bu yüzdenin en az \%70 düzeyinde olması beklenmektedir (Yıldırım ve Şimşek, 2013). Üç farklı uzman tarafından yapılan değerlendirme sonucunda araştırmacıların görüş birliğine ve görüş ayrılığına varılan kodlar belirlenerek güvenirlik yüzdesi hesaplanmış ve bulgularda sunulmuştur.

\section{Bulgular}

Problem çözme stratejilerinin süreç becerilerine (formüle etme, yürütme ve yorumlama, değerlendirme) göre sınıflandırılmasında, problem çözme stratejileri eğitimi verilen çalışma grubu öğrencilerinin PÇT'ye ilişkin çözümleri, içerik analiz yöntemi kullanılarak 3 uzman tarafından analizi gerçekleştirilmiştir. Yapılan analizler sonucunda "Sistematik Liste Yapma", "Tahmin ve Kontrol", “Diyagram Çizme”, "Bağıntı Bulma”, “Değişken Kullanma”, "Basitleştirme”, “Geriye Doğru Çalışma”, "Tablo Yapma" ve "Muhakeme Etme" stratejileri formüle etme, yürütme ve yorumlama, değerlendirme süreçleri açısından sınıflandırılmıştır. Problem çözme stratejilerinin matematiksel süreç becerilerine göre Şekil 1'de ortaya konulan sınıflandırmada yer aldıkları belirlenmiştir: 


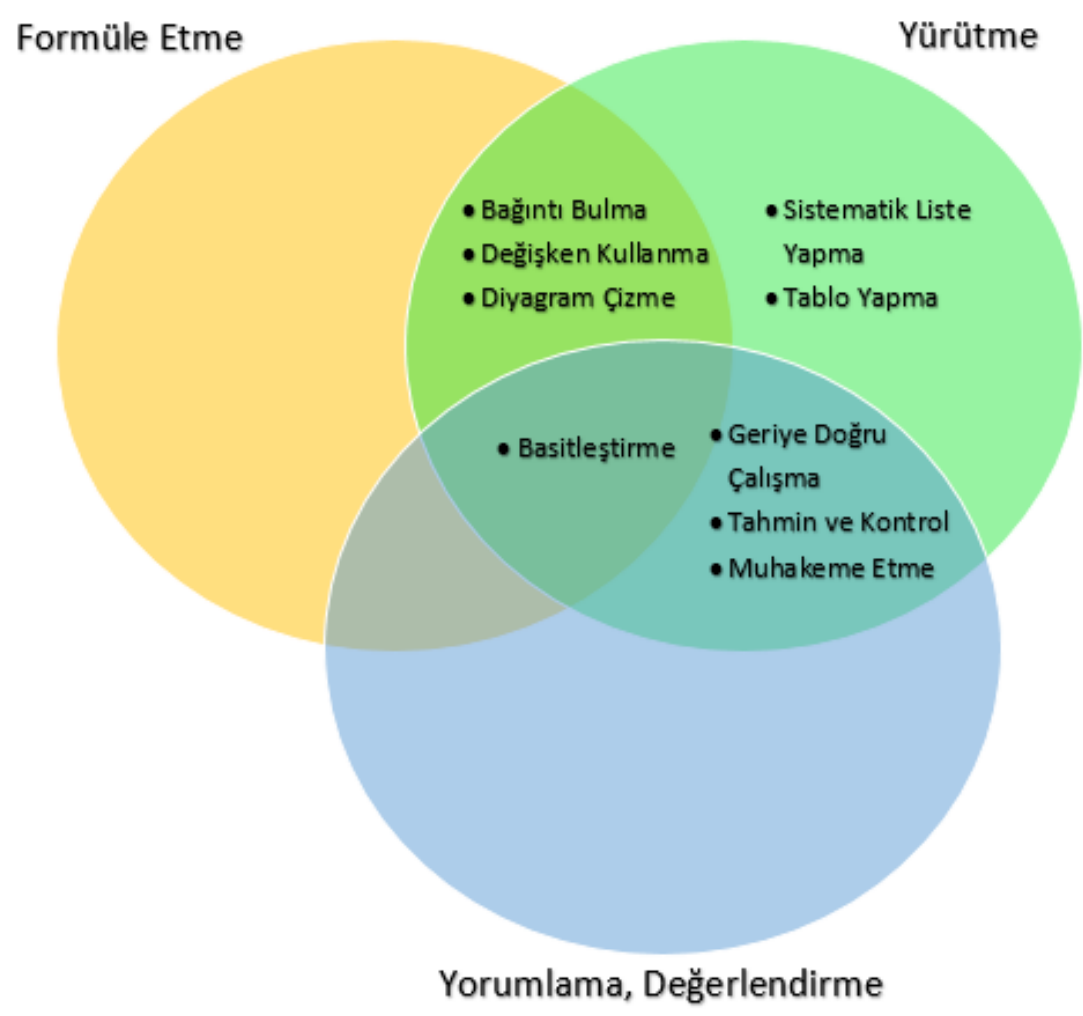

Şekil 1 Problem Çözme Stratejilerin Matematik Süreç Becerilerine Göre Sınıflandırılması

3.1. Formüle etme sürecini içeren problem çözme stratejilerine ilişkin bulgular

Yapılan analizler doğrultusunda "Bağıntı Bulma", "Değişken Kullanma", "Diyagram Çizme" ve "Basitleştirme" stratejilerinin formüle etme sürecini içeren stratejiler olduğu sonucuna ulaşılmıştır. "Bağıntı Bulma", "Değişken Kullanma" ve “Diyagram Çizme" stratejilerinin aynı zamanda yürütme sürecini, "Basitleştirme" stratejisinin ise formüle etme, yürütme ve yorumlama, değerlendirme süreçlerini içerdiği sonucuna ulaşılmıştır. Aşağıda formüle etme sürecini içeren stratejilerin sinıflandırılmasına yönelik gerekçeler, öğrenci cevap örnekleri doğrultusunda sunulmuştur:

Bă̆ıntı Bulma: PÇT'deki "bağıntı bulma" stratejisi ile çözülebilen problemlere yönelik çalışma grubunun çözümlerinin analizi sonucunda problemlerin çözümünde "Formüle Etme" sürecinin işe koşulduğu görülmüştür. Üç farklı uzmanın bu problemler için değerlendirmelerindeki uyum yüzdesi ise \%75,7 olarak hesaplanmıştır. Aşağıda örnek olarak bir öğrencinin "Altıgen Birleştirme" problemine ilişkin çözümü ve bu çözümün hangi gerekçelerle "Formüle Etme" sürecini içerdiğine ilişkin bilgiler sunulmuştur:

\section{ALTIGEN BIRLEŞTiRME}

13) Şekil 1'de verilen düzgün altıgenin bir kenarının uzunluğu $1 \mathrm{~cm}$ dir. Şekil 2'de yan yana birleștirilen iki altıgenin çevresinin uzunluğu ise $10 \mathrm{~cm}$, şekil 3 'teki yan yana birleştirilen 3 altıgenin çevresinin uzunluğu ise $14 \mathrm{~cm}$ dir. Eğer biz 7 tane altıgeni şekillerde gösterildiği gibi birleştirseydik oluşan şeklin kenar uzunluğu kaç $\mathrm{cm}$ olurdu?
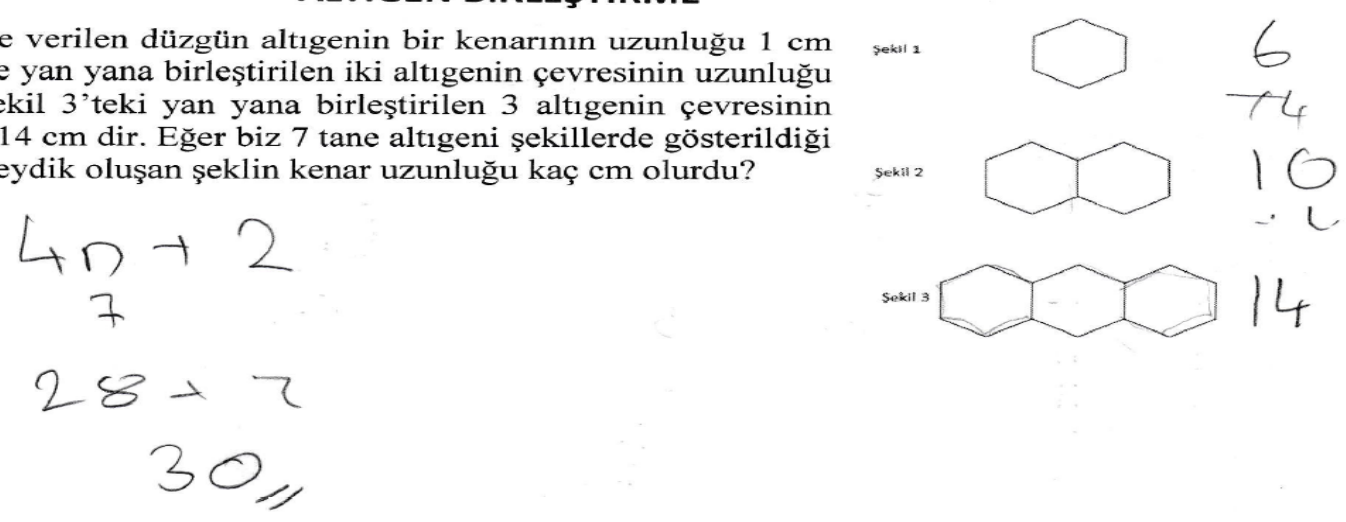
Çalışma grubundaki "D6" öğrencisinin probleme ilişkin cevabı incelendiğinde; şekil 1, şekil 2 arasındaki artışın " +4 ", şekil 2 ve şekil 3 arasındaki artışın " +4 " olduğunu fark ettiği görülmektedir. Bu çözüm şekline göre öğrencinin "problem durumundaki düzen, ilişki ve örüntüleri içeren matematiksel yapıları fark ettiği" (OECD, 2013b, s.28) söylenebilir. Bu aşamada öğrencinin formüle etme süreç becerisini kullandığı düşünülmektedir. Dolayısıyla öğrencinin bu cevabının "Formüle Etme" sürecini içerdiği görülmektedir. Ayrıca problemin çözümünde öğrencinin şekil 1'in çevresinin 6, şekil 2'nin çevresinin 10 ve şekil 3'ün çevresinin 14 olduğundan hareketle bir genellemeye ulaşttğg görülmüştür. Bir başka ifadeyle, matematiksel süreçlerden elde ettiği sonuçlara bağlı olarak bir genellemede $(4 n+2)$ bulunulmuştur. Bu açıdan da problemin çözümünde yürütme sürecine başvurulduğu söylenebilir.

Genel olarak bağıntı bulma stratejisinin formüle etme sürecini içermesine yönelik nedenleri incelediğimizde; formüle etme süreci içerisinde "problemlerde düzen ilişki ve örüntüleri içeren yapıları fark eder" davranışı yer almaktadır. Bağıntı bulma problemleri tekrar eden şekil/sayıları bulmayı içermektedir (Yazgan ve Arslan, 2019). Bağıntı bulma problemlerinin çözümünde bu tekrar eden şekil/sayı veya örüntülerin fark edilmesi gerekir. Bu durumda bağıntı problemleri bir formüle etme sürecini içermektedir. Ayrıca yürütme sürecinde "matematiksel süreçlerden elde ettiği sonuçlara bağlı olarak genelleme yapar" (OECD, 2013b, s.29) davranışı yer almaktadır. Bu doğrultuda, bağıntı bulma stratejileriyle ilgili olan problemlerin çözümü, keşfedilen örüntüden hareketle bir genelleme yapma sürecini gerektirebilir. Eğer bağıntı bulma probleminin çözümünde bir genellemede bulunulursa "Yürütme" becerisinin bu genelleme sürecinde işe koşulduğu söylenebilir.

Değişken Kullanma: PÇT'deki “Değişken Kullanma" stratejisiyle çözülebilen problemlerin "Formüle Etme" sürecini içerdiği bulgusuna ulaşılmıştır. Problemlere ilişkin içerik analizlerindeki üç uzman arasındaki uyum yüzdesi \%71,8 olarak hesaplanmıştır. Aşağıda "Orantılı Sayılar" probleme yönelik bir öğrencinin çözüm yöntemi örnek olarak sunularak çözüm sürecine ilişkin değerlendirmelere yer verilmiştir:

\section{ORANTILI SAYILAR}

14) 5, 7 ve 11 sayılarıyla orantılı olan üç sayının toplamı 207'dir. Her bir sayıyı bulunuz
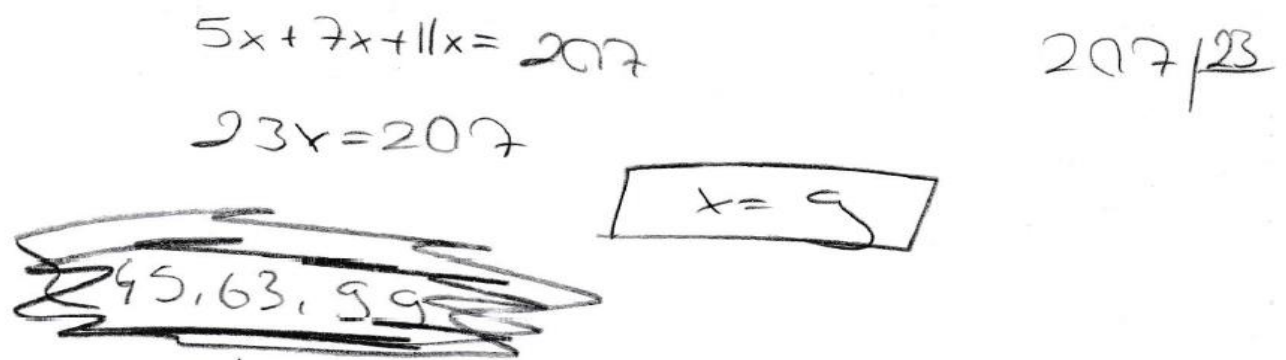

PÇT'deki orantılı sayılar problemi “Değişken Kullanma" stratejisinin işe koşulduğu bir problemdir. “D14” öğrencisinin probleme ilişkin çözümü incelendiğinde, probleme yönelik matematiksel bir yapının kurulduğu $(5 x+7 x+11 x=207)$ söylenebilir. Ayrıca, problemin çözümünde öğrencinin verilen problemi matematiksel olarak ifade ederek matematiksel bilgi ve becerilerinin kullanıldığı ve sonrasında formüle edilen problemin çözüme kavuşturulduğu görülmektedir. Formüle etme sürecinde problem durumunun matematikle ilişkisi belirlenir ve durumlar matematiksel olarak formüle edilir (OECD, 2013b). Bu doğrultuda problemin "Formüle Etme" sürecini içerdiği söylenebilir. Ek olarak, öğrencinin denklem çözme sürecinde de bulunduğu ve matematiksel yapılardan bilgi çıkarımını da gerçekleştirdiği görülmektedir. Bu durum göz önüne alındığında problemin çözümünde öğrencinin aynı zamanda yürütme süreçlerini de işe koştuğu söylenebilir.

Genel olarak değişken kullanma stratejisinin formüle etme süreci içerisinde sınıflandırılmasına yönelik nedenler incelendiğinde; formüle etme süreci "Bir durumu, uygun değişkenleri, sembolleri, diyagramları ve standart modelleri kullanarak matematiksel olarak gösterir" (OECD, 2013b, s.28) davranışını içermektedir. Değişken kullanma problemlerinde verilenler değişkenler kullanılarak 
matematiksel dünyaya aktarılabilir. Bir başka ifadeyle, bir durum matematiksel ifadeler kullanılarak matematiksel dile ve görünüme dönüştürülebilir. Bu doğrultuda, değişken kullanma problemleri "Formüle Etme" sürecini içermektedir. Ayrıca, yürütme sürecinde denklem çözme, aritmetik toplam alma gibi davranışlar gerçekleştirilmektedir. Bu bakımdan da değişken kullanma problemlerinin aynı zamanda bir denklem çözme sürecini de içerdiği düşünüldüğünde, bu problemlerin çözümü bir yürütme sürecini gerektirmektedir.

Diyagram Çizme: PÇT'deki diyagram çizme problemlerinin çözümlerine yönelik uzmanlar tarafından gerçekleştirilen içerik analizleri sonucunda bu problemlerin çözümünde "Formüle Etme" ve "Yürütme" sürecinin işe koşulduğu bulgusuna ulaşılmıştır. Uzmanların değerlendirmeleri arasındaki uyum \%90 olarak hesaplanmıştır. Aşağıda diyagram çizme stratejisinin kullanıldığı "Kuyudaki Kurbağa" probleminin çözümüne yönelik öğrenci çözüm örneğini ve problemin hangi gerekçelerden dolayı "Formüle Etme" ve "Yürütme" süreçlerini içerdiğine ilişkin açıklamalar sunulmuştur:

\section{KUYUDAKI KURBAĞA}

3) 9 metre derinliğindeki bir kuyunun dibinde bulunan bir kurbağa kuyudan çıkabilmek için çabalamaktadır. Her sıçrayışta 4 metre yükseliyor duvar kaygan olduğg için 1 metre geriye kayıyor. Kurbağa kaçıncı sıçrayışta kuyudan çıkar?


"D18” öğrencisinin "Kuyudaki Kurbağa" problemine ilişkin çözümü incelendiğinde; öğrencinin problemi çözebilmek için öncelikle bir çizim gerçekleştirdiği ve yönerge doğrultusunda işlemleri gerçekleştirdiği görülmektedir. Öğrencinin dikey olarak çizdiği şekilden hareketle çıkarımda bulunarak "4-1" olan matematiksel yapıyı fark ettiği ve bu doğrultuda çözüme ulaştığı görülmektedir. Öğrencinin çözüm için bir diyagram çizerek bu diyagramdan matematiksel örüntü ve yapıyı fark etmesi problemin çözümünde "Formüle Etme" sürecinin işe koşulduğunu göstermektedir. "Formüle Etme" sürecinin "Bir durumu, uygun değişkenleri, sembolleri, diyagramları ve standart modelleri kullanarak matematiksel olarak gösterme" ve "problemdeki ilişki ve örüntü içeren yapıyı fark etme" (OECD, 2013b, s.28) davranışlarını içerisinde barındırdığı düşüldüğünde diyagram çizme problemlerinin bir formüle etme sürecini içerdiği söylenebilir. Kuyudaki kurbağa probleminin çözümünde öğrencinin oluşturduğu "4-1" şeklindeki yapı üzerinden çıkarımlarda bulunarak problemi çözüme kavuşturması da "yürütme" becerisinin işe koşulduğu süreç olarak görülebilir. Öğrencinin çözüm bulma sürecinde diyagram oluşturarak problemi farklı açılardan değerlendirdiği, problemde ifade edilen matematiksel kuralları uyguladığı da söylenebilir.

Genel olarak diyagram çizme stratejisinin formüle etme sürecini içerisinde barındırmasının nedenleri şu şekilde açıklanabilir: Diyagram çizme stratejisinin işe koşulmasını gerektiren bir problemin çözümünde, diyagramlar çizilerek problemin farklı bir gösterimi ortaya konulmaktadır. Formüle etme sürecinin "Bir durumu, uygun değişkenleri, sembolleri, diyagramları ve standart modelleri kullanarak matematiksel olarak gösterir" davranışını içerisinde barındırması ve diyagram çizme problemlerinin verilen bir problemi matematiksel ortama aktarmada farklı model ve diyagramların oluşturmasını gerektirdiği için "Formüle Etme" sürecini içerdiği düşünülmektedir. Ayrıca "Yürütme" sürecinde 
sergilenen davranışlar arasında "Matematiksel diyagram, grafik ve yapıları oluşturur ve bunlardan matematiksel bilgi çıkarır" (OECD, 2013b, s.29) davranışı bulunmaktadır. Diyagram çizme problemlerinde matematiksel diyagramların oluşturulması ve bu diyagramlar üzerinde çıkarımlarda bulunularak problemlerin çözümün gerçekleştirilmesi, bu tür problemlerin çözümünün "Yürütme" sürecini de içerdiği düşüncesini desteklemektedir.

Basitleştirme: PÇT'deki “basitleştirme stratejisinin işe koşulduğu problemlerin formüle etme, yürütme ve yorumlama, değerlendirme süreçlerini içerdiği bulgusuna ulaşılmıştır. Problemlerin çözüm süreçlerine yönelik gerçekleştirilen içerik analizlerindeki uzman değerlendirmeleri için hesaplanan uyum yüzdesi \%76,5'tir. Aşağıda "Daire Doldurma" probleminin çözümüne yönelik bir öğrencinin çözüm yöntemi ve bu yöntemin hangi durumlardan dolayı formüle etme sürecini içerdiğine yönelik bilgiler sunulmuştur:

\section{DAIRE DOLDURMA}

15) 1'den 19'a kadar olan sayıları aşağıda verilen 19 dairenin içerisine öyle bir yerleştirin ki bir doğrultudaki her 3 sayının toplamı aynı sonucu versin. (Şekilde koyu olarak işaretlenenler bir doğrultuyu ifade etmektedir.)


“D10" öğrencisinin daire doldurma problemine ilişkin cevabı incelendiğinde; öncelikle öğrencinin problemi daha kolay analiz edebilmek için kendi oluşturduğu daha basit bir şekil üzerinden işlemi gerçekleştirdiği görülmektedir. Başka bir deyişle, matematiksel analiz yapabilmek için problemin daha basit bir yapısının oluşturulduğu söylenebilir. Problemin daha basit bir yapısının oluşturulmasında "Formüle Etme" sürecinin kullanıldığı söylenebilir. Öğrencinin basitleştirdiği yapıda 1'den 5'e kadar olan sayıların nasıl yerleştirileceğini keşfederek ana problemdeki sayıları bu doğrultuda yerleştirdiği görülmektedir. Basitleştirdiği yapıdan probleme yönelik çıkarım aşamasında ise öğrencinin "Yürütme" sürecini kullandığı söylenebilir. Öğrencinin kendi oluşturduğu daha basit modelde matematiksel çözümün makul olup olmadığını değerlendirdiği, bir başka ifadeyle basit olarak oluşturduğu modelden birtakım sonuçlar ürettiği ve daha sonra bu sonuçları değerlendirerek ana problemin çözümünde kullandığı görülmektedir. Bu durum dikkate alındığında, problemin çözümünde "Yorumlama, Değerlendirme" sürecinin de işe koşulduğu düşünülmektedir.

Genel olarak basitleştirme stratejisinin içerdiği süreçlere ilişkin nedenler incelendiğinde; basitleştirme stratejisine yönelik problemlerin çözümü, durumların verilenden daha basit olarak sadeleştirilmesini gerektirebilir. Formüle etme sürecine ilişkin davranışlar arasında "matematiksel analiz yapabilmek için durumların sadeleştirilmesi" (OECD, 2013b) yer almaktadır. Bu doğrultuda, basitleştirme problemlerinin bir formüle etme sürecini içerdiği söylenebilir. Ayrıca, basitleştirme stratejisinin işe koşulduğu problemlerin çözümünde bir bağlam içerisindeki problemin benzer ve daha basit bir yapısı kurularak problem basitleştirilir. Basitleştirilen problemin çözümünden yola çıkarak asıl probleme ilişkin değerlendirmelerde bulunulabilir. Bu çözüm süreci içerisinde daha basit ve benzer bir yapının kurulmasının yürütme sürecini, bu yapıdan çıkarımlarda bulunarak asıl probleme ilişkin çözümlerin gerçekleştirilmesinin ise yorumlama, değerlendirme sürecini gerektirdiği düşünülmektedir. 


\subsection{Yürütme sürecini içeren problem çözme stratejilerine ilişkin bulgular}

Uzmanlar tarafından gerçekleştirilen içerik analizi sonucunda; "Sistematik Liste Yapma" ve "Tablo Yapma" stratejilerinin sadece yürütme sürecini içerdiği belirlenirken, "Bağıntı Bulma", "Değişken Kullanma" ve "Diyagram Çizme" stratejilerinin ise hem yürütme hem de formüle etme süreçlerini içerdiği ortaya konulmuştur. "Geriye Doğru Çalı̧̧ma", "Tahmin ve Kontrol" ve "Muhakeme Etme" stratejilerinin hem yürütme hem de yorumlama, değerlendirme süreçlerini içerdiği, "Basitleştirme" stratejisinin ise yürütme, formüle etme ve yorumlama, değerlendirme süreçlerini içerdiği sonucuna ulaşılmıştır. Bağıntı Bulma”, "Değişken Kullanma", "Diyagram Çizme” ve "Basitleştirme" stratejilerine yönelik bulgular formüle etme sürecinde yer verildiği için bu bölümde ilgili stratejilere değinilmemiştir. "Sistematik Liste Yapma" ve "Tablo Yapma" stratejilerinin hangi gerekçeler doğrultusunda yürütme sürecini içerdiğine yönelik bilgiler aşağıda çözüm örnekleriyle birlikte sunulmuştur. "Geriye Doğru Çalışma", "Tahmin ve Kontrol" ve "Muhakeme Etme" stratejilerine yönelik bulgular ve gerekçeler yorumlama değerlendirme sürecini içeren problem çözme stratejilerine yönelik bulgular bölümünde bahsedilecektir.

Sistematik Liste Yapma: PÇT'deki sistematik liste yapma stratejisiyle çözülebilen problemlerin çözümünde yürütme sürecinin işe koşulduğu belirlenmiştir. Üç uzman tarafından gerçekleştirilen içerik analizi sonucunda uzmanlar arasındaki uyum \%100 olarak hesaplanmıştır. Aşağıda bu problemlere ilişkin bir öğrencinin çözüm yöntemi örnek olarak sunularak çözümün hangi gerekçelerden dolayı "Yürütme" sürecini içerdiğine yönelik açılamalarda bulunulmuştur:

\section{HACKER}

1) Bir bilgisayar programındaki şifreyi çözmek isteyen hacker, şifrelerin 8 tek sayı kullanılarak 20 sayısının elde edilmesini sağlayan sayı gruplarının olduğunu keşfediyor. 8 tek sayı kullanarak 20'nin elde edilmesini sağlayan tüm șifreler nelerdir?
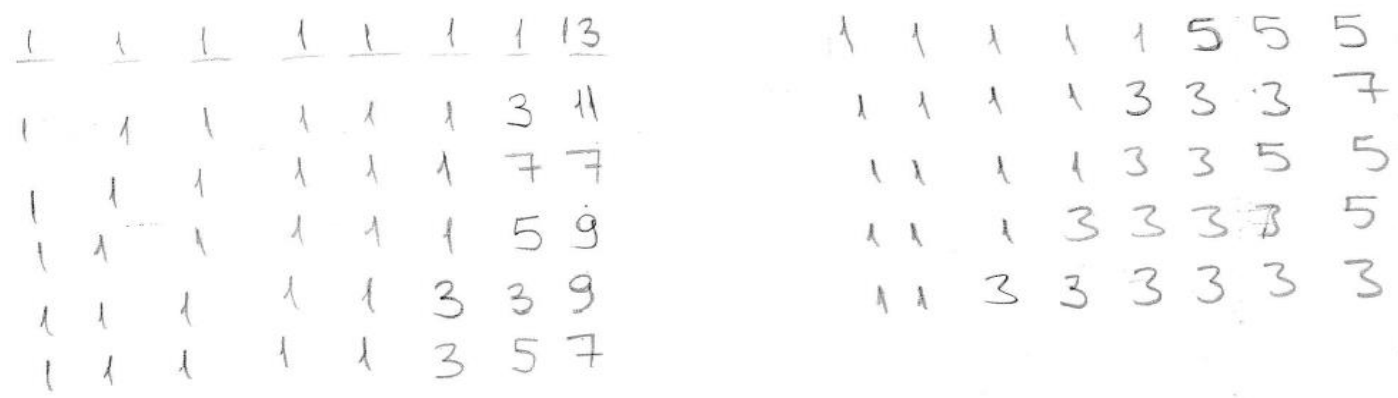

"Hacker" problemi sistematik liste yapma stratejisiyle çözülebilen bir problemdir. "D4" öğrencisinin probleme yönelik çözümü incelendiğinde; öğrencinin olası bütün durumları listelediği, dikkatli ve sistemli bir sıralama gerçekleştirdiği görülmektedir. Ayrıca öğrencinin problemde belirtilen 8 tek sayı kuralı doğrultusunda matematiksel varsayımlara dayalı bir akıl yürütme gerçekleştirdiği, çözüm bulmak için matematiksel kuralları göz önüne alarak, matematiksel dünyada çıkarımlarda bulunarak bir sonuca ulaştığı görülmektedir. Bu durumlar dikkate alındığında bu problemin çözümünde "Yürütme" sürecinin işe koşulduğu söylenebilir.

Tablo Yapma: PÇT'deki tablo yapma stratejisini gerektiren problemlerin çözümünde "Yürütme" sürecinin kullanıldığı sonucuna ulaşılmıştır. Uzmanların içerik analizi sonucunda tablo yapma problemlerindeki uzman değerlendirmeleri arasındaki uyum \%77,8 olarak hesaplanmıştır. Aşağıda "Marangoz" problemine ilişkin bir öğrencinin çözümü verilerek bu problemlerin hangi gerekçelerden dolayı "Yürütme" sürecini gerektirdiğine ilişkin açıklamalarda bulunulmuştur: 


\section{$12+4^{6} \quad 9+$ MARANGOZ}

8) Bir marango 3 ayaklı tabureler ve 4 ayaklı masalar yapmaktadır. Bir günün sonunda 31 ayak kullanılmışsa, o gün kaç masa ve kaç tabure yapmış olabilir?

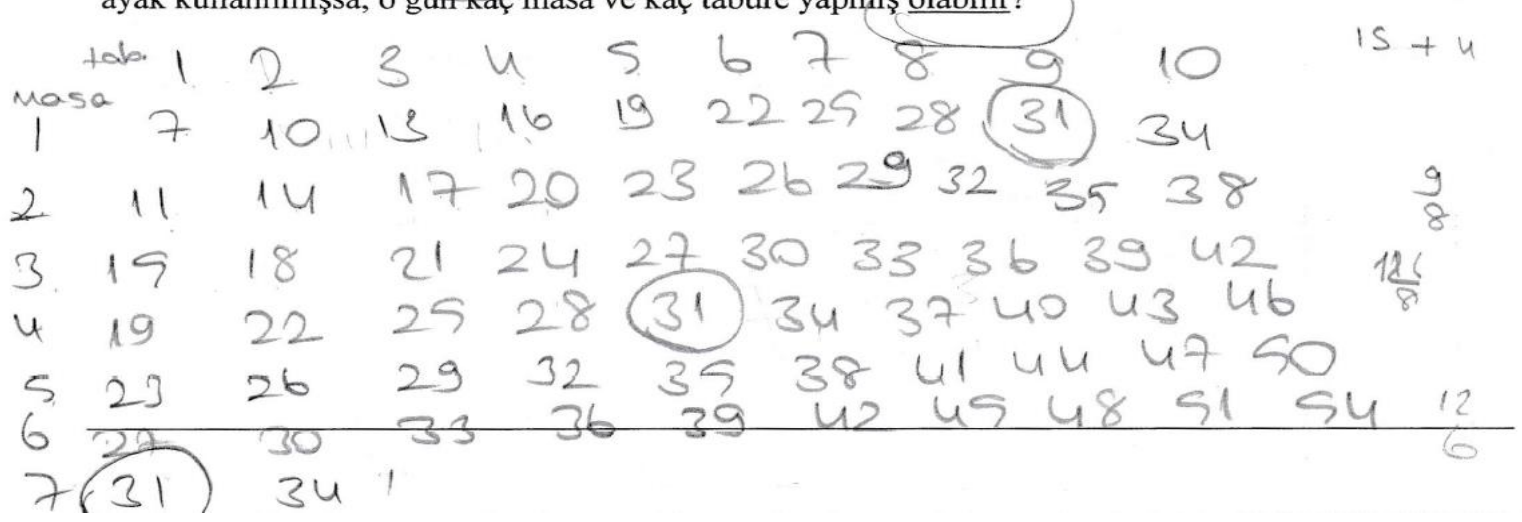

Tablo yapma stratejisi ile çözümü gerçekleştirilen "Marangoz" problemine ilişkin “D3" öğrencisinin çözümü incelendiğinde, öğrencinin gerçek yaşam durumundaki problemin çözümünde matematiksel bir tablo oluşturduğu ve oluşturulan bu tablo üzerinden sınırlılıkları belirleyerek çözüme ulaştığı görülmektedir. Oluşturulan tablodan verilen bilgiler doğrultusunda çıkarımlarda bulunulduğu görülmüştür. Bu bilgiler doğrultusunda problemin çözümü için tablo oluşturma aşamasında ve tablonun verilen bilgiler ışığında çıkarımlar yapılmasında "Yürütme" süreci kullanılmıştır.

Tablo yapma ile ilgili problemlerde yürütme sürecinin işe koşulmasına ilişkin gerekçeleri incelediğimizde; tablo yapma stratejisi, bir problem bağlamında dağınık olarak sunulan verilerin sınıflandırılması veya sıralanmasını sağlayarak bilgiler arasındaki yapı veya ilişkilerin görülmesini kolaylaştırır. Tablo yapma stratejisi kullanılarak problemdeki verilerin düzenlenmesi, problemin çözümüne ilişkin çıkarımların yapılması sağlanabilir. Oluşturulan tablolardan hareketle çıkarımlarda bulunulması yürütme sürecini gerektirmektedir. Bir başka ifadeyle, yürütme sürecinde tablo ve grafik okuma, matematiksel varsayımlar veya tablo ve grafiklerden çıkarımlar yapma, şekillerin gösterimi gibi beceriler işe koşulmaktadır. Bu bakımdan tablo yapma stratejisinin "Yürütme" sürecini içerdiği ifade edilmiştir.

3.3. Yorumlama, değerlendirme sürecini içeren problem çözme stratejilerine ilişkin bulgular

"Geriye Doğru Çalışma" ve "Tahmin ve Kontrol" ve "Muhakeme Etme" stratejilerinin hem "Yorumlama, Değerlendirme" hem de "Yürütme" süreçlerini içerdiği bulgusuna ulaşılmıştır. "Basitleştirme" stratejisinin ise "Yorumlama, Değerlendirme", "Formüle Etme" ve "Yürütme" süreçlerinde yer aldığı belirlenmiştir. "Basitleştirme" stratejisine yönelik bulgulara, formüle etme sürecini içeren problem çözme stratejilerine ilişkin bulgular bölümünde yer verildiği için bu bölümde değinilmemiştir. Aşağıda "Geriye Doğru Çalışma" ve "Tahmin ve Kontrol" ve "Muhakeme Etme" stratejilerinin içerdiği süreçlere yönelik bulgular ve örnek cevaplara yer verilmiştir:

Geriye Doğru Çalışma: PÇT'deki geriye doğru çalışma stratejisi ile ilgili problemlerin çözümüne yönelik gerçekleştirilen içerik analizleri sonucunda uzmanlar arasındaki uyum $\% 78,9$ olarak hesaplanmıştır. Aşağıda geriye doğru çalışma stratejisinin kullanıldığı "Hesap Ödeme" problemine ilişkin bir öğrencinin cevabı örnek olarak sunularak bu problemin hangi gerekçelerden dolayı "Yorumlama, Değerlendirme" sürecini içerdiğine yönelik açılamalarda bulunulmuştur: 


\section{HESAP ÖDEME}

7) Bir lokanta sahibi yemek yiyen müşterilerine, hesap ödemesi yapılırken; "Kasanın içine bak ne kadar para varsa kendin de o kadar koy, 2 lira al ve çık" diyor. Dördüncü müşteri kasaya baktığında para olmadığını görüyor. Müşterilerden önce kasada kaç lira vardı?
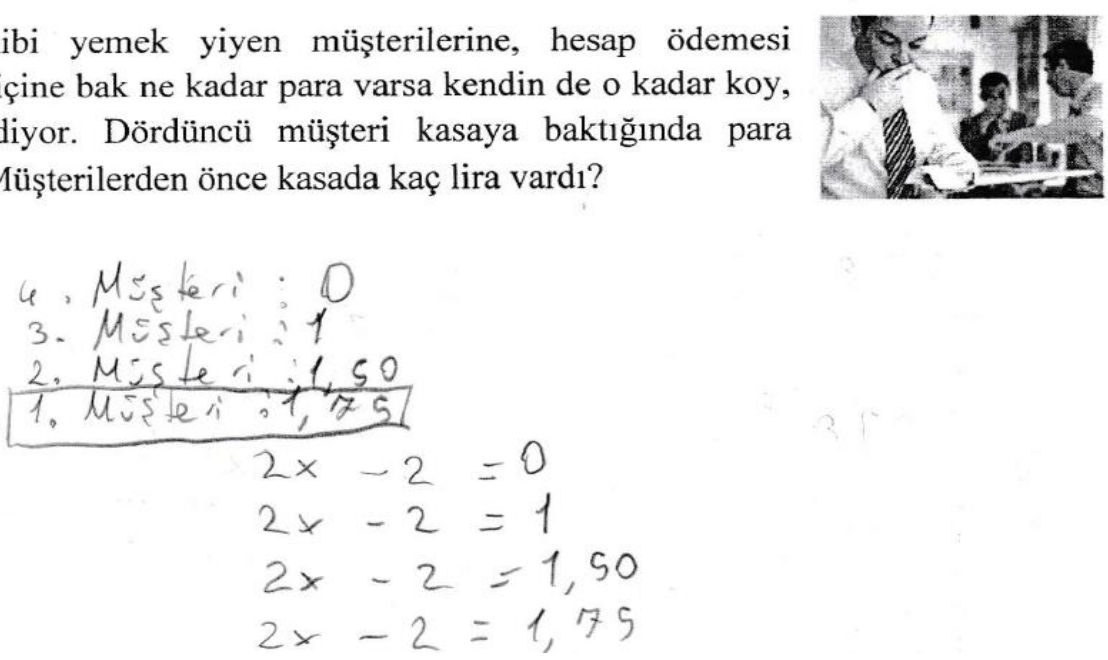

“Hesap Ödeme” problemine ilişkin “D7” öğrencisinin çözümü incelendiğinde; en son gelen (dördüncü) müşterinin bilgisi doğrultusunda kasada para olmadığından hareketle 1. müşteriye geriye doğru kasada kalan paraları hesaplayarak sonuca ulaştığı görülmektedir. Bu problemin çözümünde matematiksel sonuca gerçek dünya içeriği doğrultusunda yorumlanarak ulaşıldığı söylenebilir. Bir başka ifade ile problemin çözümü için bir model oluşturulduğu $(2 x-2)$ ve problemin çözümünde modelin sınırlılıklarının belirlendiği de göze çarpmaktadır. Problemin çözümü incelendiğinde gerçek yaşam bağlamına yönelik bir problem olduğu ve çözüme, gerçek yaşam bağlamındaki bir gerekçeden yola çıkarak geriye doğru çözümler yoluyla ulaşıldığı görülmektedir. Bu durumlar dikkate alındığında problemin çözümünde "Yorumlama, Değerlendirme" sürecinin işe koşulduğu belirlenmiştir. Ayrıca ilgili problemden elde edilen sonucun, problemde verilen kural doğrultusunda sağlamasının yapılarak sonucun değerlendirilmesi bu problemin "Yorumlama ve Değerlendirme" sürecinde olduğunun bir diğer göstergesidir.

Genel olarak geriye doğru çalışma stratejisiyle çözülebilen problemlerin yürütme ve yorumlama, değerlendirme süreçleri içerisinde sınıflandırılmasının nedenleri incelendiğinde: Geriye doğru çalışma problemlerinin çözümünde problemde verilen "kural, algoritma veya yapıların uygulanması" gerekmektedir. Ayrıca problemde ifade edilen kural veya varsayımlardan hareketle bir akıl yürütme sürecinin işe koşulması problemin çözümü için önem arz etmektedir. Bu durumlar göz önüne alındığında geriye doğru çalışma problemlerinde bir yürütme süreci gerekmektedir. Elde edilen sonucun doğruluğunun kontrol edilmesi, problemde verilen ilk durumdan son duruma doğru çözümün değerlendirilmesinin yapılması gibi matematiksel çıktıların veya sonuçların değerlendirilmesinde ise "Yorumlama, Değerlendirme" sürecinin işe koşulduğu söylenebilir. Bu durumlar dikkate alındığında geriye doğru çalışma problemleri yürütme ve yorumlama, değerlendirme süreçlerinde sınıflandırılmıştır.

Tahmin ve Kontrol: PÇT'deki tahmin ve kontrol stratejisine yönelik problemlerin çözümünün "Yürütme" ve "Yorumlama, Değerlendirme" süreçlerini gerektirdiği sonucuna ulaşılmıştır. Gerçekleştirilen içerik analizleri sonucunda uzmanlar arasındaki uyum \%97,3 olarak hesaplanmıştır. Aşağıda tahmin ve kontrol stratejisinin kullanıldığı "Bilgi Yarışması" probleminin çözümüne ilişkin bir öğrencinin cevabı ve bu problemin hangi gerekçelerden dolayı "Yürütme" ve "Yorumlama, Değerlendirme" süreçlerini gerektirdiğine ilişkin açıklamalarda bulunulmuştur: 


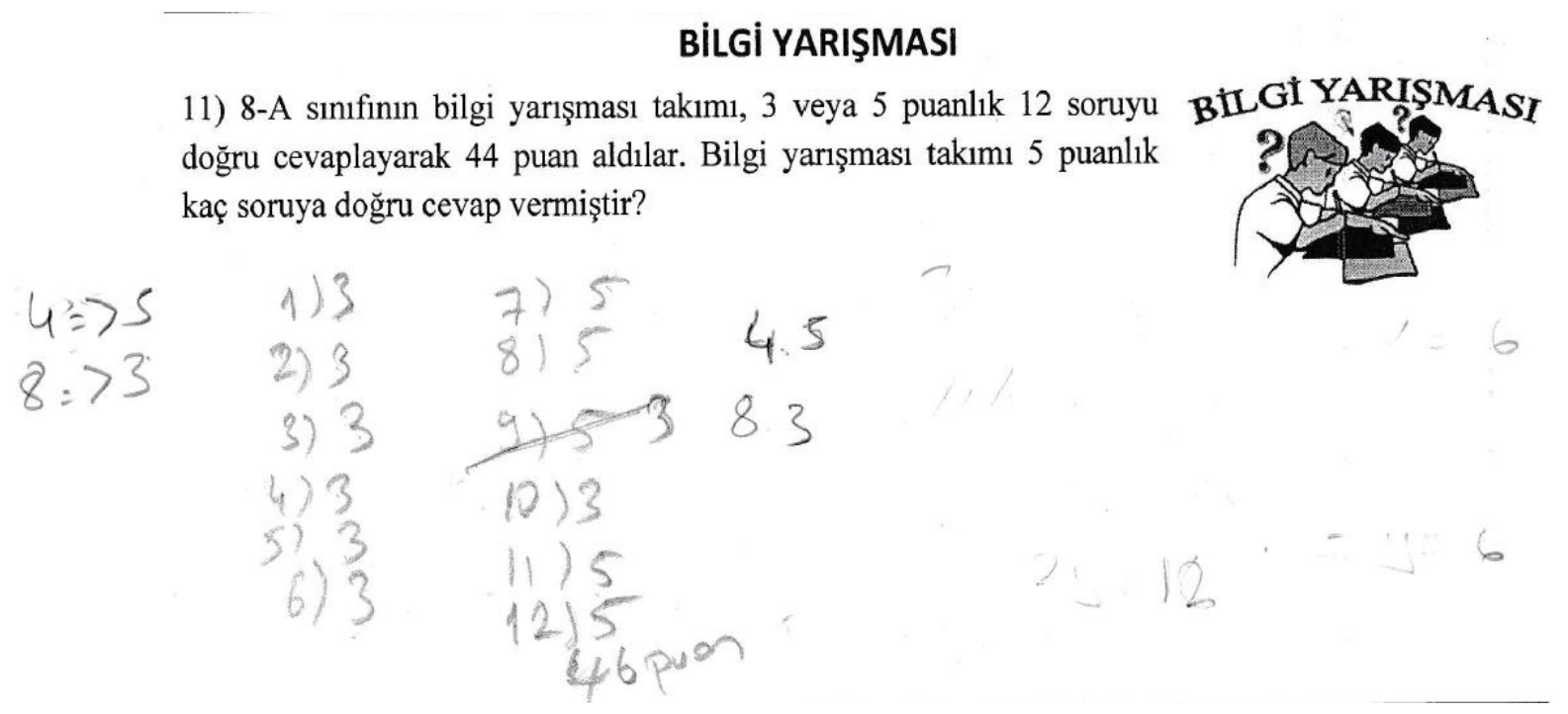

“Tahmin ve Kontrol" stratejisinin kullanıldığg “Bilgi Yarışması" problemine ilişkin "D12" öğrencisinin cevabı incelendiğinde; öncelikle öğrencinin problemin çözümüne ilişkin bir varsayımda bulunduğu ve bu varsayımı test ederek toplam puanı " 46 " olarak hesapladığı görülmektedir. Daha sonraki süreçte 46 puanın fazla olduğu ve 44 puana ulaşmak için 5 puanlık bir soruyu 3 puanlık soruya dönüştürmesi gerektiği çıkarımında bulunmuştur. Problemin çözümünde varsayımlardan yola çıkarak mantıklı çıkarımlarda bulunulması ve bu çıkarım doğrultusunda tahminin değiştirilmesinde "Yürütme" sürecinin işe koşulduğu düşünülmektedir. Problemin çözümüne yönelik ilk gerçekleştirilen tahmin, bir değerlendirme süreci içerisinde kontrol edilerek yapılan tahminin 46 puana eşit olduğu hesaplanmış ve değerlendirme süreci doğrultusunda tahmin değiştirilerek düzeltilmiştir. İlk gerçekleştirilen tahminin değiştirilmesi ve sonrasındaki tahminin kontrolünde elde edilen sonucun değerlendirilmesi yapılmıştır. $\mathrm{Bu}$ durumlar dikkate alındığında gerçekleştirilen çözümde "Yürütme" ve "Yorumlama, Değerlendirme" süreçlerinin işe koşulduğu düşünülmektedir.

Genel olarak tahmin ve kontrol stratejisini gerektiren problemlerin yürütme ve yorumlama, değerlendirme süreçlerini içermesine ilişkin nedenleri incelediğimizde; tahmin ve kontrol problemlerinin varsayımlardan yola çıkarak problemin sonucunun tahmin edilmesi ve daha sonrasında elde edilen tahmin kontrol edilerek değerlendirilmesini gerektirmektedir. Varsayımlardan hareketle yeni tahminlerin ortaya konulması ve bu varsayımlar doğrultusunda yeni cevapların üretilmesinin bir yürütme sürecini gerektirdiği, gerçekleştirilen tahminin kontrol edilerek değerlendirilmesinde ise matematiksel çıktıların veya sonuçların değerlendirildiği düşüncesinden hareketle "yorumlama, değerlendirme" sürecinin işe koşulduğu görülmektedir. Bu durumlardan dolayı tahmin ve kontrol problemlerinin "Yürütme" ve "Yorumlama, Değerlendirme" süreçleri içerisinde yer aldığı söylenebilir.

Muhakeme Etme: PÇT'deki muhakeme etme stratejisinin kullanıldığı problemlerin çözümüne yönelik gerçekleştirilen uzman değerlendirmeleri sonucunda bu problemlerin çözümünde "Yorumlama, Değerlendirme" ve "Yürütme" süreçlerinin işe koşulduğu belirlenmiştir. Uzmanlar arasındaki uyum yüzdesi ise \%93 olarak hesaplanmıştır. Aşağıda "“Araba Yarışı” probleminin çözümüne yönelik bir öğrencinin çözüm yöntemi sunularak hangi gerekçelere göre bu problemin "Yürütme" ve "Yorumlama, Değerlendirme" süreçlerini içerdiğine ilişkin değerlendirmelerde bulunulmuştur: 


\section{ARABA YARIŞI}

9) Beş araba bir yarış̧ katılmışțr. Yarışa katılan arabaları̧n üzerindeki numaralar su sekildedir:

1733

5824

9762

19

14

- En büyük numaralı araba yarışı en son bitirmiştir.

6465

21
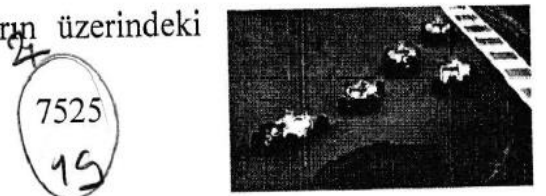

- 1. olan arabayla, 2. olan arabaların basamaklarındaki rakamların toplamı aynıdır.

- 3. ve 4. olan arabaların birler basamağındaki rakam tektir.

- 2. ve 3. olan arabaların numaraları 5'e bölünebilmektedir.

Verilen bilgilere göre arabalar yarışı hangi sırada bitirmiştir?

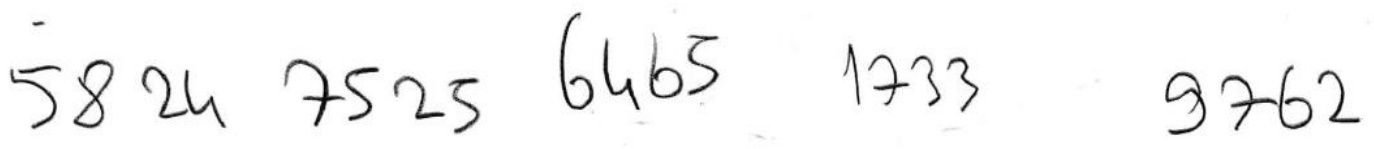

D19" öğrencisinin probleme ilişkin çözümü incelendiğinde; probleme ilişkin matematiksel çıtıların değerlendirilerek bir muhakeme sürecinin gerçekleştirildiği görülmektedir. Öğrenci öncelikle probleme ilişkin çıktılardan hareketle numaralarla arabaları eşleştirmiştir. Problemdeki çıktılar doğrultusunda öğrencinin en büyük numaralı aracın sonuncu olduğu bilgisinden hareketle sonuncu aracın "9762" numaralı araç olduğu, daha sonra 1. ve 2. aracın rakamlarının toplamının aynı olduğu bilgisinden hareketle her bir yarış aracının rakamlarının toplandığı görülmektedir. 2. ve 3. olan araçların numaralarının 5'e bölündüğü bilgisinden hareketle 1. olan aracın numarası tespit edilmiştir. Bu tür değerlendirmeler doğrultusunda bir yürütme sürecinin işe koşulduğu düşünülmektedir. Ayrıca problemde belirtilen durumların gerçek yaşam durumuna transfer edilerek yorumlandığı da söylenebilir. Problemde belirtilen çıktılar değerlendirilerek cevaba ulaşılmıştır. Bu durumlar göz önüne alındığında da problemin çözüm sürecinde "Yorumlama, Değerlendirme" süreci işe koşulmuştur.

Genel olarak muhakeme etme problemlerinin yürütme ve yorumlama, değerlendirme süreçlerini içermesine ilişkin gerekçeleri incelediğimizde; muhakeme etme problemleri mantıksal çıkarım veya düşünme gerektirmektedir. Bu durumlar göz önüne alındığında "Yürütme" süreçlerinde de varsayımlardan hareketle çıkarımlar yapma davranışı yer almaktadır. Bu doğrultuda muhakeme etme problemlerinin yürütme sürecini gerektirdiği düşünülmektedir. Ayrıca problemdeki çıktılar doğrultusunda bir değerlendirmede bulunularak sonucun kontrol edilmesi veya bu değerlendirmeler doğrultusunda çıkarımlar yapılarak sonuca ulaşılmasında ise "Yorumlama, Değerlendirme" süreci işe koşulmaktadır. Bu durumlar dikkate alındığında muhakeme etme problemlerinin "Yürütme" ve "Yorumlama, Değerlendirme" süreçleri içerisinde yer aldığı söylenebilir.

\section{Tartışma, Sonuç ve Öneriler}

Gerçekleştirilen sınıflandırma sonucunda stratejilerin tamamı yürütme süreci içinde yer aldığ1 belirlenmiştir. PISA uygulamalarına bakıldığında matematik okuryazarlık başarısı ile ilgili problemlerin yarısında yürütme sürecinin işe koşulduğu görülmektedir (Anıl, Özkan ve Demir, 2015). Yürütme becerisi, matematik eğitiminde öğrencilere kazandırılması gereken temel beceriler arasında gösterilmektedir (MEB, 2013; NCTM, 2000). Yapılan sinıflandırmayla tüm stratejilerin yürütme sürecinde yer alması yürütme sürecinin matematik eğitimi açısından önemini ortaya koymaktadır. Yürütme süreci denildiğinde işlemlerin yapılması, matematiksel araçların kullanılması, grafik ve diyagramların oluşturulması ve matematiksel çıkarımlarda bulunulması akla gelmektedir (Altun, 2014). Ersoy (2006) 1-8 matematik öğretim programına atıfta bulunarak öğrencilerin yürütme becerisini kazanabilmeleri için "mantığa dayalı çıkarımlarda bulunabilme" ve "tahminde bulunabilme" gibi becerilerin geliştirilmesi gerektiğini ifade etmektedir. Ortaokul matematik öğretim programında ise yürütme becerilerinin kazandırılması için dikkate alınması gereken durumlar arasında mantıklı genellemelerde ve çıkarımlarda bulunma, referans noktası dikkate alarak tahminde bulunma ve ölçümlerin sonucuna dair tahminlerde bulunma gibi durumlardan bahsedilmektedir (MEB, 2013). Elde 
edilen bulgulara göre sadece yürütme becerisinin işe koşulduğu sistematik liste yapma stratejisi, bir düzen içerisinde verilerin mantıksal olarak sıralanması, olası bütün durumların belli bir sistem içerisinde sıralanmasını gerektirmektedir. Bir başka ifadeyle, sistematik liste yapma stratejisiyle verilenlerden hareketle mantıksal olarak bir yürütme gerçekleştirilerek verilerin sistemli olarak düzenlenmesi veya sıralaması yapılmakta ve bu işlemler esnasında mantıklı çıkarımlarda bulunulmaktadır. Tablo yapma stratejisinde ise bilgiler düzenlenerek tablo oluşturulur ve bu düzenlemelerden hareketle istenilen sonuca veya matematiksel çıkarıma ulaşılabilir. Tablo yapma stratejisi birçok matematiksel kural veya genellemenin iç içe yer aldığı durumları görmek ve bu durumlardan hareketle problemin sonucunu tahmin edebilmek için önemli bir strateji olarak görülmektedir (Altun, 2014). Tablo yapma stratejisinde gerçek yaşam durumunda verilen bilgiler sınıflandırılarak veya bir düzen içerisinde anlaşılır bir biçime dönüştürülerek problemler çözüme kavuşturulabilir. Yine tablo yapma stratejisiyle var olan örüntülerin keşfedilmesi ya da matematiksel olarak verilen ifadelerin farklı temsil biçimleriyle gösterilmesi sağlanabilir. Yürütme sürecinde ise tablo ve grafik okuma, matematiksel diyagram, grafik ve yapıların oluşturulması (Anıl, Özkan ve Demir, 2015), yine bu tablolardan çıarımlarda bulunulması eylemleri yer alır. Bu bilgiler tablo yapma ve sistematik liste yapma stratejilerinin yürütme süreci içerisinde yer almasını destekler niteliktedir.

"Bağıntı Bulma”, “Değişken Kullanma” ve "Diyagram Çizme" stratejilerinin hem formüle etme hem de yürütme süreçlerinin işe koşulduğu sonucuna ulaşılmıştır. Formüle etme sürecinin örüntüler içeren matematiksel yapının fark edilmesi ve bu yapıların semboller kullanarak cebirsel dille gösterilmesi gibi davranışlarda etkin olduğu görülmektedir (Anıl, Özkan ve Demir, 2015). Yürütme süreci ise bir genelleme sürecini içerisinde barındırmakta (OECD, 2013b) ve denklem çözme gibi bazı matematiksel işlemlerde kullanılmaktadır (Anıl, Özkan ve Demir, 2015). Bağıntı bulma stratejisinde öğrencilerin matematiksel yapıyı fark etmesi ve örüntünün genel bir denkleminin ortaya konulması problemin çözümünde kritik öneme sahiptir. Bağıntı bulma stratejisinde gerçek yaşam durumunda verilen problemlerin matematiksel dünyaya aktarılması sürecinde formüle etme, ilgili bağıntının fark edilmesi ve formüle edilen problemin çözüme kavuşturulmasında ise yürütme sürecinin işe koşulması gerekmektedir. Bu bakımdan bağıntı bulma stratejisinde formüle etme ve yürütme süreçlerinin etkin olduğu söylenebilir. Değişken kullanma stratejisinde ise bilinmeyen için herhangi bir işaret, şekil veya sembol kullanılarak matematiksel bir eşitlik yazarak problemin çözüme kavuşturulması gerçekleşir. Stratejinin özünde değişken kullanarak problem bağlamında verilen ilişkileri eşitlik veya eşitsizlik olarak yazma yer almaktadır (Yazgan ve Arslan, 2019). Değişken kullanma stratejisinde farklı değişkenlerin kullanılmasıyla verilenlerin matematiksel dünyaya aktarımı gerçekleştirilir. Matematiksel dünyaya denklem biçiminde aktarılan problemin çözümünde ise yürütme sürecinin harekete geçirildiği söylenebilir. Bu durumlar dikkate alındığında değişken kullanma problemlerinde formüle etme ve yürütme süreçlerinin işe koşulduğu düşünülmektedir. Aydoğdu ve Keşan (2016) çalışmalarında mantıksal çıkarım ve yaşantıya bağlı çıkarım düzeyindeki öğrencilerin en çok kullandıkları stratejilerden bir tanesinin diyagram çizme stratejisi olduğunu ifade etmektedir. Yürütme sürecinde mantıksal çıkarımlar, matematiksel bilgi çıkarımları, matematiksel diyagram ve yapıların oluşturulması gibi davranışların sergilendiği görülmektedir (Anıl, Özkan ve Demir, 2015). Aydoğdu ve Keşan'ın (2016) çalışmalarında ortaya koyduğu bilgiler ve PISA'nın matematik süreç becerilerine ilişkin ortaya koyduğu davranışlar diyagram çizme stratejisinin formüle etme ve yürütme süreçleri içerisinde sınıflandırılmasını destekler niteliktedir.

"Tahmin ve Kontrol", "Geriye Doğru Çalışma" ve "Muhakeme Etme" stratejilerinde "Yürütme" ve "Yorumlama, Değerlendirme" süreçlerinin işe koşulduğu sonucuna ulaşılmıştır. Tahmin ve kontrol stratejisi, verilenlerden hareketle problemin cevabına ilişkin bir tahminde bulunma ve bu tahmini kontrol etme sürecini içermektedir (Altun, 2014). Gerçekleştirilecek olan tahminin matematiksel verilerden veya bir bağlam içerisinde sunulan probleme ilişkin ortaya konulmuş bilgilerden hareketle ortaya atılmasında yürütme sürecinin işe koşulduğu söylenebilir. Bir başka ifadeyle, problemdeki verilenler göz önüne alınarak matematiksel varsayımlarda bulunulur. Tahminde bulunma aşamasında verilenlerden hareketle bir akıl yürütme süreci işe koşulmaktadır. Gerçekleştirilen tahminin kontrol aşamasında ise ortaya konulan veya belirlenen çözümün makul olup olmadığı ortaya konulur. Kontrol 
aşamasında ise bulunan çözüm yöntemi test edilip değerlendirilir, tahminin doğru değilse elde edilen sonuç doğrultusunda başka bir tahminde bulunulur (Yazgan ve Arslan, 2019). Bu süreç doğru cevaba ulaşıncaya kadar devam eder. Yeni tahminde bulunma ve bu tahmine yönelik değerlendirmelerde yürütme ve yorumlara, değerlendirme süreçleri kullanılmaktadır. Bu durumlar tahmin ve kontrol stratejisinin hem yürütme hem de yorumlama, değerlendirme süreçlerinde yer aldığı sonucunu desteklemektedir. "Geriye Doğru Çalışma" stratejisinde problemde verilen algoritma veya kural doğrultusunda yürütme süreci kullanılmaktadır. Verilen kural veya algoritmadan hareketle ilk durumdaki sonuca ulaşıldığında sonucun doğruluğunun kontrol edilmesi aşamasında da değerlendirme sürecinin işe koşulacağı söylenebilir. Muhakeme etme stratejisinde ise bu stratejiye yönelik problemlerde "böyle ise şöyle olur" veya "bu durumdan şu sonuç çıkar" şeklinde çıkarımlar yapılabilir (Baykul, 2014). Bir başka ifadeyle, muhakeme etme stratejisinde verilenler doğrultusunda mantıksal çıkarımların yapıldığı söylenebilir. Yürütme sürecinin de çıkarımlarda bulunmayı gerektirmesi (OECD, 2013a) muhakeme stratejisinin bu süreç içerisinde sinıflandırmasını destekler niteliktedir. Yorumlama, değerlendirme sürecinde ise sonuçların ne kadar doğru veya uygulanabilir olduğu konusunda mantıklı çıkarımlar yapması gerektiği ve bu durumu gerçek yaşam durumunda değerlendirmesi gerektiği ifade edilmektedir (Anıl, Özkan ve Demir, 2015). Bu durumlar dikkate alındığında "Muhakeme Etme" stratejisinin "Yürütme" ve "Yorumlama, Değerlendirme" süreçlerini gerektirdiği söylenebilir. Dolayısıyla bu tanımlamalar arasındaki uyum gerçekleştirilen sınıflandırmayı desteklemektedir.

"Basitleştirme" stratejisinde tüm matematiksel süreçlere ihtiyaç duyulduğu sonucuna ulaşılmıştır. Yazgan (2007) çalışmasında öğrencilerin en fazla zorlandıkları stratejilerden birinin basitleştirme stratejisi olduğunu, Azak (2015) ise sekizinci sınıf öğrencilerinin en az kullandıkları stratejiler arasında basitleştirme stratejisinin olduğunu ifade etmektedir. Bu durumun sebebinin basitleştirme stratejisinin birden fazla süreçle ilişkili olmasından dolayı olduğu düşünülmektedir. Basitleştirme stratejisinin tüm süreçleri içerisinde barındırmasından dolayı basitleştirme problemlerinin üst düzey beceri gerektirdiği söylenebilir. Bu durum Yazgan'ın (2007) bu stratejinin üst düzey sinıflarda anlatılması gerektiği düşüncesini destekler niteliktedir. Ayrıca bazı çalışmalarda problem çözmede başarılı başarısız ayrımı yapmada güçlü etkiye sahip stratejiler arasında basitleştirme stratejisinin de olduğu kanısına varılmıştır (Altun ve Memun, 2008; Aydoğdu ve Keşan, 2016). Basitleştirme stratejisinin birden fazla matematiksel süreç becerileriyle ilgili olmasının Altun ve Memnun (2008) ve Aydoğudu ve Keşan (2016) sonuçlarını desteklediği söylenebilir.

Matematiksel süreç becerileri öğrencilere kazandırılması gerek temel beceriler arasındadır (Polat, Bingölbali ve Bindak, 2015). Fakat, Bingölbali, Gören ve Arslan (2016) çalışmalarında öğretmenlerin ders kitaplarındaki kazanımlara yönelik matematiksel süreç becerilerini tam olarak açıklayamadıklarını, Özgen (2019) ise öğretmen ve öğretmen adaylarının matematiksel süreç becerilerine yönelik problem kurmada güçlük çektiklerini belirtmektedir. Ülger, Bozkurt ve Altun (2020) ise çalı̧̧malarında matematik okuryazarlık problemlerinde matematiksel süreç becerileri açısından güçlüklerle karşılaşıldığını belirterek süreçlerle ilgili uygulamaların arttırılması gerektiğini vurgulamıştır. Gerçekleştirilen çalışmalar dikkate alındığında öğretmenlerin ve öğrencilerin matematiksel süreç becerilerinde sorun yaşadıkları görülmektedir. Bu durumun literatürde matematiksel süreçlerin nasıl kazandırılacağı, matematiksel süreçlere yönelik eğitimlerin nasıl planlanması gerektiği, ne tür uygulama ve etkinliklerin süreç becerilerine katkı sağlayacağına yönelik yeterince çalışma olmamasından (Erdoğan ve Özdemir-Erdoğan, 2013) kaynaklandığı düşünülmektedir. Ayrıca matematiksel süreç becerilerine yönelik yapılan çalışmaların büyük çoğunluğunun betimsel tanımlamalarla sınırlı olduğu, var olan soruna yönelik çözüm üreten çalışmaların yeteri düzeyde olmadığı ortaya konulmuştur (Ülger, Bozkurt ve Altun, 2020). Yapılan sinıflandırma dikkate alınarak tasarlanacak eğitimler doğrultusunda matematiksel süreç becerilerinin gelişimine katkı sağlanabilir. Gerçekleştirilen sınıflandırmayla matematiksel süreç becerilerinin nasıl kazandırılacağı, ne tür uygulama ve etkinliklerin süreç becerilerine olumlu etkisinin olacağı sorularının cevabına bir nebze olsun 1şık tutulacağı düşünülmektedir. Bu doğrultuda süreç becerilerine göre 
sınıflandırılan problem çözme stratejilerine yönelik problemler kullanılarak ilgili süreç becerilerinin gelişimi incelenebilir.

Ortaya konulan sınıflandırma çerçevesinde ilgili problem çözme stratejilerinin öğretimi gerçekleştirilerek öğrencilerin ilgili süreç becerilerinin gelişip gelişmediğinin belirlenmesine yönelik yeni araştırmalar gerçekleştirilebilir. Formüle etme, yürütme ve yorumlama, değerlendirme süreç becerilerine yönelik problemlerden hareketle bu problemlerin hangi problem çözme stratejilerini içerdiğine yönelik çalışmalar da ortaya konulabilir. Gerçekleştirilen sınıflandırma çerçevesinde bir süreç becerisi içeren veya birden fazla süreç becerisi içeren stratejilerin ayrı ayrı öğretimleri arasında farklılıkların olup olmadığı, bu durumların öğrencilerin matematik okuryazarlık başarı düzeylerine etkisini ortaya koyan çalışmalar da gerçekleştirilebilir.

Elde edilen sonuçlar doğrultusunda problem çözme stratejilerine yönelik eğitimler gerçekleştirilen sınıflandırma göz önüne alınarak düzenlenebilir. Eğitimler öncelikle bir süreç içeren stratejilerden birden fazla süreç becericin işe koşulduğu stratejilere doğru düzenlenebilir. Düşük düzeydeki sınıflarda birden fazla sürecin işe koşulduğu stratejilerin kullanılmasından ziyade sadece bir sürecin işe koşulduğu stratejilerin eğitimi gerçekleştirilebilir. Birden fazla sürecin işe koşulduğu stratejiler düşük düzeydeki sınıflarda basit düzeyde anlatılabilir. Gerçekleştirilen sınıflandırmadan faydalanılarak formüle etme, yürütme ve yorumlama değerlendirme süreçlerinin geliştirilmesinde ilgili stratejilere yönelik problemler kullanılabilir.

Problem çözme stratejilerinin sınıflandırması süreç becerileri dikkate alınarak gerçekleştirilmiştir. Literatürde problem çözme stratejilerinin sınıflandırılmasına yönelik çalışmalara rastlanmamıştır. $\mathrm{Bu}$ doğrultuda problem çözme stratejilerinin gerçek yaşam durumlarına, konu ve beceri alanları gibi çeşitli sınıflandırmaların yapılması literatüre katkı sağlaması ve strateji öğretimi açısından faydalı olacağı düşünülmektedir.

\section{Kaynakça}

Akkaya, R., \& Memnun, D. S. (2012). Öğretmen adaylarının matematiksel okuryazarlığa ilişkin özyeterlik inançlarının çeşitli değişkenler açısından incelenmesi. Dicle Üniversitesi Ziya Gökalp Ĕ̆itim Fakültesi Dergisi, 19, 96-111.

Akyüz, G., \& Pala, N. M. (2010). PISA 2003 sonuçlarına göre öğrenci ve sınıf özelliklerinin matematik okuryazarlığına ve problem çözme becerilerine etkisi. İlköğretim Online, 9(2), 668-678.

Alsina, A., Maurandi, A., Ferre, E., \& Coronata, C. (2020). Validating an Instrument to Evaluate the Teaching of Mathematics Through Processes. International Journal of Science and Mathematics Education, 1-19.

Altun M., \& Memnun D. S. (2008). Mathematics teacher trainees' skills and opinions on solving nonroutine mathematical problems. Journal of Theory and Practice in Education, 4(2), 213-238.

Altun, M. (2014). Ortaokullarda (5, 6, 7 ve 8. sinflarda) matematik öğretimi. (10. Baskı). Bursa: Alfa Aktüel.

Altun, M., \& Arslan, Ç. (2006). İlköğretim öğrencilerinin problem çözme stratejilerini öğrenmeleri üzerine bir çalışma. Uludă̆ Üniversitesi Ĕ̆itim Fakültesi Dergisi, 19(1), 1-21.

Anıl, D., Özkan, Y. Ö., \& Demir, E. (2015). PISA 2012 araştırması ulusal nihai rapor. PISA uluslararası öğrenci değerlendirme programı. Ankara: İşkur Matbaacılık.

Artut, P. D., \& Tarım, K. (2006). İlköğretim öğrencilerinin rutin olmayan sözel problemleri çözme düzeylerinin çözüm stratejilerinin ve hata türlerinin incelenmesi. Çukurova Üniversitesi Sosyal Bilimler Enstitüsü Dergisi, 15(2), 39-50.

Aydoğdu, M. Z., \& Keşan, C. (2016). 9. sınıf üstün zekalı öğrencilerin geometri problem çözme stratejileri. Ĕ̆itim ve Öğretim Araştırmaları Dergisi, 5(2), 48-55. 
Azak, S. (2015). Ortaokul 8. sınıf öğrencilerinin problem çözmede kullandıkları stratejilerin ve üstbilişsel davranışlarının belirlenmesi. (Yayımlanmamış yüksek lisans tezi). Karadeniz Teknik Üniversitesi Eğitim Bilimleri Enstitüsü, Trabzon.

Baykul, Y. (2014). Ortaokulda Matematik Öğretimi (5-8. Sinıflar). Ankara: Pegem Akademi Yayınları.

Bingölbali, F., Gören, A. E., \& Arslan, S. (2016). Matematik öğretmenlerinin ders kitaplarını okuma düzeyleri: öğretim programının hedefleri doğrultusunda bir inceleme. Turkish Journal of Computer and Mathematics Education, 7(2), 460-485.

Büyüköztürk, Ş., Çakmak Kılıç, E., Akgün, Ö.E., Karadeniz, Ş., \& Demirel, F. (2014). Bilimsel araştırma yöntemleri. (17. Baskı). Ankara: Pegem Akademi.

Cai, J. (2003). Singaporean students' mathematical thinking in problem solving and problem posing: an exploratory study. International journal of mathematical education in science and technology, 34(5), 719-737.

Creswell, J. W. (2013). Research design: Qualitative, quantitative, and mixed methods approaches. Thousand Oaks, CA: Sage publications.

Çelebioğlu, B., \& Yazgan, Y. (2009). İlköğretim öğrencilerinin bağıntı bulma ve sistematik liste yapma stratejilerini kullanma düzeyleri. Uludă̆ Üniversitesi Ĕ̆itim Fakültesi Dergisi, 22(1), 15-28.

Çilingir, E., \& Artut, P. D. (2016). Gerçekçi matematik eğitimi yaklaşımının ilkokul öğrencilerinin başarılarına, görsel matematik okuryazarlığı özyeterlik algılarına ve problem çözme tutumlarına etkisi. Turkish Journal of Computer and Mathematics Education, 7(3), 578-600.

Dönmez, N. (2002). Illköğretim 2. ve 3. sinı öğrencilerinin problem çözme stratejilerini kullanabilme düzeyleri üzerine bir çalışma. (Yayımlanmamış yüksek lisans tezi). Uludă̆ Üniversitesi Sosyal Bilimler Enstitüsü, Bursa.

Elia, I., Van Den Heuvel-Panhuizen, M., \& Kolovou, A. (2009). Exploring strategy use and strategy flexibility in non-routine problem solving by primary school high achievers in mathematics. ZDM, 41(5), 605.

Erdoğan, A. ve Özdemir-Erdoğan, E. (2013). Didaktik durumlar teorisi ışığında ilköğretim öğrencilerine matematiksel süreçlerin yaşatılması. Ahi Evran Üniversitesi Kırşehir Eğitim Fakültesi Dergisi (KEFAD), 14 (1), 17-34.

Ersoy, Y. (2006). İlköğretim matematik öğretim programındaki yenilikler-i: amaç, içerik ve kazanımlar. Ilköğretim Online, 5(1), s. 30-44.

Grouws DA (1999). Handbook of research on mathematics teaching and learning. Shanghai Education Press, $356-382$.

Işık, C., \& Kar, T. (2011). İlköğretim 6, 7 ve 8. sınıf öğrencilerinin sayı algılama ve rutin olmayan problem çözme becerilerinin incelenmesi. Ahi Evran Üniversitesi Ĕ̆itim Fakültesi Dergisi, 12(1), 57-72.

Johnson, B., \& Christensen, L. (2014). Eğitim araştırmaları: nicel, nitel ve karma yaklaşımlar. (Çev edt: Demir, S. B.) Ankara: Eğiten Kitap.

Kaosa-ard, C., Erawan, W., Damrongpanit, S., \& Suksawang, P. (2015). How to classify the diversity of seventh grade students' mathematical process skills: An application of latent profile analysis. Educational Research and Reviews, 10(11), 1560-1568.

Karasar, N. (2008). Bilimsel Araştırma Yöntemi. Ankara: Nobel Yayın Dağıtım.

Kaytancı N. (1998). Illköğretim dördüncü sınıf matematik öğretiminde öğrencilere problem çözme ile ilgili kritik davranışları kazandırılmasında öğrenme düzeyinin belirlenmesi. (Yayımlanmamış yüksek lisans tezi). Pamukkale Üniversitesi Sosyal Bilimler Enstitüsü, Denizli. 
Kolovou, A., Van den Heuvel-Panhuizen, M., \& Bakker, A. (2009). Non-routine problem solving tasks in primary school mathematics textbooks-A needle in a haystack. Mediterranean Journal for Research in Mathematics Education, 8(2), 31-68.

Krulik, S., \& Rudnick, J. A. (1989). Problem solving: A handbook for senior high school teachers. Boston: Allyn and Bacon.

Mabilangan, R. A., Limjap, A. A., \& Belecina, R. R. (2011). Problem-solving strategies of high school students on non-routine problems: A case study. Alipato: A Journal of Basic Education, 5, 23-46

Miles, M.B., \& Huberman A.M. (1994). Qualitative data analiysis (2th ed.). London New Delhi: Sage Publication.

Milli Eğitim Bakanlığı (MEB). (2013). Ortaokul matematik dersi 5-8. sinfflar öğretim programı. Ankara: MEB Talim Terbiye Başkanlığı Yayınları.

Milli Eğitim Bakanlığı (MEB). (2018). Matematik dersi öğretim programı (İlkokul ve ortaokul 1, 2, 3, 4, 5, 6, 7 ve 8. Sinfflar). http://mufredat.meb.gov.tr/Dosyalar/201813017165445-MATEMAT\% C4\%B0K \%20\%C3\%96\%C4\%9ERET\%C4\%B0M\%20PROGRAMI\%202018v.pdf 'den alınmıştır.

Mohd, N., \& Mahmood, T. F. P. T. (2011). The effects of attitude towards problem solving in mathematics achievements. Australian Journal of Basic and Applied Sciences, 5(12), 1857-1862.

National Council of Teachers of Mathematics (NCTM). (2000). Principles and standarts for school mathematics. Reston, VA: National Council of Teachers of Mathematics.

Niss M, Blum W, Galbraith P (2007). Introduction. In W.Blum, P.L.Galbraith, H.Henn \& M. Niss (eds.), Modelling and Applications in Mathematics Education: The 14th ICMI Study. New York.

Niss, M., \& Højgaard, T. (2019). Mathematical competencies revisited. Educational Studies in Mathematics, 102(1), 9-28.

Olkun, S., Şahin, Ö., Akkurt, Z., Dikkartın, F. T., \& Gülbağcı, H. (2009). Modelleme yoluyla problem çözme ve genelleme: İlköğretim öğrencileriyle bir çalışma. Ĕ̆itim ve Bilim, 34(151), 65-73.

Organisation for Economic Co-operation and Development (OECD). (2013a). PISA 2012 results: what students know and can do - student performance in mathematics, reading and science (Volume I). Paris: OECD Publishing. http://dx.doi.org/10.1787/9789264201118-en

Organisation for Economic Co-operation and Development (OECD). (2013b). PISA 2012 assessment and analytical framework: Mathematics, reading, science, problem solving and financial literacy. Paris: OECD Publishing. http://dx.doi.org/10.1787/9789264190511-en

Özgen, K. (2019). Problem-Posing Skills for Mathematical Literacy: The Sample of Teachers and PreService Teachers. Eurasian Journal of Educational Research, 84, 177-212.

Özdemir, F., Duran, M., \& Kaplan, A. (2016). Ortaokul öğrencilerinin görsel matematik okuryazarlı̆̆1 özyeterlik algıları ile problem çözme beceri algılarının incelenmesi. Kuramsal Eğitimbilim Dergisi, 9(4), 532-554.

Polat, S., Bingölbali, E. ve Bindak, R. (2015). Ortaokul matematik öğretmenlerinin matematiksel süreç becerilerine ilişkin bilgileri. 2. Türk Bilgisayar ve Matematik Eğitimi Sempozyumu'nda sunulan bildiri, Adıyaman Üniversitesi, Adıyaman.

Posamentier, A. S. \& Krulik, S. (2009). Problem solving in mathematics, grades 3-6: Powerful strategies to deepen understanding. CA: Corwin.

Ramnarain, U. (2014). Empowering educationally disadvantaged mathematics students through a strategies-based problem solving approach. The Australian Educational Researcher, 41(1), 43-57. 
Reys, R. E., Lindquist, M. M., Lambdin, D.V. \& Smith, N. L. (2007). Helping Pupils Learn Mathematics. New Jersey: John Wiley \& Sons, Inc.

Schoenfeld, A. H. (1999). Looking toward the 21st century: Challenges of educational theory and practice. Educational Researcher, 28(7), 4-14.

Soytürk, İ. (2011). Sınıföğretmeni adaylarının matematik okuryazarlı̆̆ı öz-yeterlikleri ve matematiksel problem çözmeye yönelik inançlarının araştırılması. (Yayımlanmamış yüksek lisans tezi). İstanbul Üniversitesi Sosyal Bilimler Enstitüsü, İstanbul.

Stacey, K., \& Turner, R. (2015). Assessing mathematical literacy: The PISA experience. New York, NY: Springer.

Stanic, G., \& Kilpatrick, J. (1988). Historical perspectives on problem solving in the mathematics curriculum. In R. I. Charles \& E. A. Silver (Eds.), The teaching and assessing of mathematical problem solving (pp. 1-22). Reston, VA: NCTM.

Umay, A. (2003). Matematiksel muhakeme yeteneği. Hacettepe Üniversitesi Eğitim Fakültesi Dergisi, 24, 234-243.

Ülger, T. K., Bozkurt, I., \& Altun, M. (2020). Matematik Öğrenme-Öğretme Sürecinde Matematik Okuryazarlığına Odaklanan Makalelerin Tematik Analizi. Eğitim ve Bilim, 45(201), 1-37.

Woodward, J., Beckmann, S., Driscoll, M., Franke, M., Herzig, P., Jitendra, A., ... \& Ogbuehi, P. (2012). Improving mathematical problem solving in grades 4 through 8: A practice guide (NCEE 2012-4055). Washington, DC: National Center for Education Evaluation and Regional Assistance, Institute of Education Sciences, U.S. Department of Education. Retrieved from http://files.eric.ed.gov/fulltext/ED532215.pdf

Yazgan, Y. \& Arslan, Ç. (2019). Matematiksel sıradışı problem çözme stratejileri ve örnekleri (7. Baskı). Ankara: Pegem Akademi Yayınları.

Yazgan, Y. (2007). Dördüncü ve beşinci sınıf öğrencilerinin rutin olmayan problem çözme stratejileriyle ilgili gözlemler. İlköğretim Online, 6(2), 249-263.

Yazgan, Y., \& Bintaş, J. (2005). İlköğretim dördüncü ve beşinci sınıf öğrencilerinin problem çözme stratejilerini kullanabilme düzeyleri: Bir öğretim deneyi. Hacettepe Üniversitesi Eğitim Fakültesi Dergisi, 28, 210-218.

Yıldırım, A. (1999). Nitel araştırma yöntemlerinin temel özellikleri ve eğitim araştırmalarındaki yeri ve önemi. Ĕgitim ve Bilim, 23(112), 7-17.

Yıldırım, A., \& Şimşek, H. (2013). Sosyal bilimlerde nitel araştırma yöntemleri. Ankara: Seçkin Yayıncılık. 